ÇOMÜ Uluslararası Sosyal Bilimler Dergisi 1(2), 47-80, 2016

COMU International Journal of Social Sciences 1(2), 47-80, 2016

\title{
Çanakkale Cephesinde Karargâhlar
}

\section{Öz}

Ahmet ESENKAYA*

Bu araştırmada 5 nci Ordu'nun kuruluşu öncesi ve sonrasında, Müttefiklerin bölgeden çekilmesine kadar Çanakkale Boğazı, civar sahillerde ve karada icra edilecek olan savunma faaliyetlerinin yürütülmesi için kurulacak olan karargâhlarla ilgili bilgi vermek amaçlanmıştır. Bu amaca ulaşmak için post-pozitivist paradigma altında nitel araştırma yöntemlerinden doküman analizi tekniği kullanılmıştr. Mevcut dokümanlar askeri ve devlet arşivlerinden, askeri eserlerden ve anılardan taranarak elde edilmiştir. Yapılan araştırma sonucunda Osmanlı Devleti'nin güneyden gelecek tehlikelere karşı, Boğaz'ın her iki yakasına kaleler yaparak, sahil savunma topları yerleştirerek İstanbul'u savunma çabası, bölgede savaş öncesi ciddi bir hazırlı̆̆ının var olduğunu göstermektedir. Yönetim, Avrupa'da patlak veren savaşa paralel olarak, süreç çok hızlı işlediğinden dolayı, ne yapılacaksa onunla ilgili süratle karar almaya ve hemen yapmaya çalışmıştr. Bu çabanın özünde karargâhların da ayrı bir önemi vardır.

Başkomutanlık, Müstahkem Mevki Komutanlığı, ordu, kolordu, tümen, grup, bölge, alay karargâhları ile mevcut bilgiler titizlikle taranmıştr. Peşinden, savunma ve stratejik anlamda karargâhın kurulacağı yerin tespiti, faal hale getirme, karargâhın tefrişi, karargâh görevlileri ve görevleri tanzimi, muhabere görevlerinin ifası, yazışmalara cevap hazırlanması, istihbari bilgileri değerlendirme, üst birimlerle irtibat kurma, stratejik toplantılar yapma, 'harp ceridesi' hazırlama, emirler hazırlama, ziyaretçileri ağırlama ve uğurlama, mutat günlük işleri kesintisiz yapma gibi pek çok hizmetin bir arada nasıl yapıldı̆̆ı göz önüne serilmeye çalışıımışır.

Anahtar kelimeler: Çanakkale Savaşı, Karargâh, I. Dünya Harbi

\section{Headquarters in Çanakkale Wall}

\begin{abstract}
The aim of this research is to provide needed information about headquarters to be founded for the defense activities in the Dardanelles, surrounding costs, and lands until the allied forces withdraw from the region before and after the establishment of the $5^{\text {th }}$ army. For this aim, document analysis technique was adopted out of qualitative researches in post-positivist paradigm. Current documents were handled by military and the state archives, military artifacts and the memories. To sum up, it was clearly seen that Ottoman Empire built castles in each part of the Dardanelles for the defense, and coastal artillery for the defense of Istanbul. This shows that there is serious preparation before war. Ottoman Empire started to manage and decide for preparation in parallel with the war in Europe. For this, this endeavor is honored by headquarters.

All the unities such as Commander in Chief, Fortress Command, the army corps, divisions, groups, regions, and headquarters of ridicule were investigated meticulously. Then, it was tried how to manage many service in one hand such as defense and strategic sense, the determination of where to set up headquarters, bringing into operation, refurbishment of the headquarters, headquarters officials and tasks, the fulfillment of their communication tasks, answering correspondence preparation, intelligence information assessment, establishing contact with the upper unit, making strategic meetings, 'war news bulletin' preparation, preparing orders visitors are welcome and farewell, not the usual daily work without interruption.

Keywords: Çanakkale War, Headquarters, World War I
\end{abstract}

Yrd. Doç. Dr., Çanakkale Onsekiz Mart Üniversitesi, Eğitim Fakültesi, Sosyal Bilgiler Öğretmenliği, Tarih Eğitimi, aesenkaya@comu.edu.tr 


\section{GíRiş}

İstanbul'un kapısı konumundaki Çanakkale Boğazı'nı, kolay geçebileceklerinden emin olan Müttefikler, Türk direnişi karşısında yaklaşık bir yıl inatla işgale devam etmişlerdir. Vatan gibi diğer kutsal değerleri uğruna gözünü kırpmadan canını feda etmeye hazır kahramanlar karşısında, hezimete uğramalarına rağmen, her iki taraftan toplam yarım milyon insanın zayiatına sebep oluncaya kadar inat etseler de, bir başarı elde edemeden çekip gitmişlerdir. Çanakkale Cephesi'nin her bir karesi araştırılabilir niteliğe sahiptir. Çalışma gündemi olan 'karargâh'ların askeri birim olarak işlevleri gündeme taşınacaktır. Zaten terminolojide karargâh, silahlı kuvvetler ile ilişkili herhangi bir birlik ya da birimin, kumandan ile yardımcı şube ve bölümlerinden oluşan, askeri emir-komuta zincirine tabi organize kuruluş olarak tanımlanır.

Avrupa'da Birinci Dünya Savaş başlar başlamaz 2 Ağustos 1914'te Harbiye Nezareti'nin üst katındaki Genelkurmay Başkanlığı'nın bulunduğu katta 'Karargâh-ı Umumi ve Başkumandanlık Vekâleti'nin kurularak Harbiye Nazırı Enver Paşa'nın göreve başlaması, karargâhın ciddiyetini göstermesi açısından büyük önem arz eder.

Karargâhla ilgili Çanakkale'deki durum da aynı hassasiyeti barındırır. Boğaz girişinde Birleşik filonun gün be gün çoğalmaya başlamasıyla, zaten mevcut olan ve karargâhı Çimenlik kalesinde bulunan Çanakkale Müstahkem Mevki Komutanlığı, bağlı bulunduğu İstanbul'daki Komutanlık ve Genel Karargâhla, daha da çoğalan yoğun bir bilgi trafiğini yürütmeye çalışmıştır. Mesela Çanakkale Boğaz girişindeki tabyaların 25 Şubat 1915 bombardımanında tahribi sebebiyle, karargâh daha güvenli yer olan üç kilometre güneybatısındaki Hacıpaşa Çiftliği'ne taşımıştır.

Çalışma hazırlanırken Genelkurmay Personel Başkanlığı Askerî Tarih ve Stratejik Etüt Daire Başkanlığı Arşivi (ATASE) ve Başbakanlık Osmanlı Arşivi (BOA), Çanakkale gündemli kitapları askeri temel başvuru kaynakları olmuştur. 5 nci Ordu Gelibolu, Bayır Köyü, Yalova Köyü karargâhları, Çanakkale Müstahkem Mevki Komutanlığı Çimenlik Kalesi ve Hacıpaşa Çiftliği karargâhları,3 ncü Kolordu Maltepe ve Kemalyeri karargâhları, Asya yakasındaki Kalvert Çiftliği karargâhı,19 ncu Tümen Bigalı Köyü, Kocadere, Kemalyeri, Düztepe karargâhları, Anafartalar Grup Komutanlığı Çamlıtekke karargâhı, hemen akla gelen karargâhlardan sadece birkaçıdır. Anı kitaplarından da karargâhlarla ilgili gündemin canlılığını sağlayacak kadar bilgiye ulaşılma mümkün olmuştur.

Müttefikler, donanmaları başta olmak üzere modern harp malzemesine sahip olduklarından dolayı, her zaman ölçüsüz davranışlarda bulunmuşlardır. İstanbul'un savunucuları da süreci çok hızlı işletmeye ve kararları çok çabuk alıp hemen uygulamaya çalışmışlardır. Tüm bunları da karargâhlarında yapmışlardır.

Cephelerde karargâh demek, muharebenin kalbinin attğı yer demektir. Savaşın bizzat kendisinin olağanüstülüğü dikkate alındığında, her şeye her an hazır olmayı gerektiren bir ortam olduğu için, karargâhta yaşanan hayat, kesintisiz 7/24 saatlik zamanın tamamını kuşatır. Karargâh olarak kullanılan yapılar bazen bir kale, bir bina veya bir çadırdır. Muharebe alanında öncelikle karargâhın kurulacağı yerin tespiti çok büyük öneme sahiptir. İlk başta savaşın hâlihazırda yaşanıyor olması sebebiyle, kara, deniz ve hava saldıılarından etkilenmeyecek, korunaklı bir yerin seçilmiş olması gereklidir. Bu kifayet etmediğinde de son çare olarak karargâhın yerinin değiştirilmesi yoluna gidilir.

Karargâh mahallinin seçimine paralel olarak, muharebe alanlarında hâkim ve korunaklı alanların seçilmesi de o derece gereklidir. 
Bu seçim esnasında ordugâhlarla, muharebe idare yerleriyle irtibat da mutlaka dikkate alınır. Kısa sürede karargâhı faal hale getirmek için masa, sandalye, dolap, yatak, mutfak, banyo, lavabo gibi kişisel intiyaçlara cevap veren tefrişatın temini zorunludur. Telefon, telgraf hizmetlerinin ifası için muhabere görevlerinin her an hazır olması lazımdır. Harita, kroki gibi üzerinde çalışılacak materyallerle kırtasiye malzemelerinin her an hazır bulundurulması da gereklidir. Dahası yazışmalara cevap hazırlanması, istihbari bilgilerin değerlendirmesi, üst birimlerle irtibat kurulması, taktik toplantlar yapılması, 'harp ceridesi' yazılması, bir üst birime gönderilmesi, emirler hazırlama; ziyaretçileri ağırlama ve uğurlama, mutat günlük işleri kesintisiz yapma gibi pek çok hizmet karargâhlarda yapılır. Karargâh subayı dâhil karargâh görevlileri ve görevleri tespit ve tayinine ihtiyaç vardır. Bu yapının ve içinde yaşayanların güvenliği için savunma birliği bulundurulması kuraldır.

Bu çalışmanın planlanmasında, en az dört beş defa kurgunun değiştirilmesi intiyaç duyulmuş olup, sonunda kronolojik yöntemin uygulanmasına karar verilmiştir. Diğer taraftan kara muharebelerinin en az iki, üç, dört farklı alanda devam ettiği dönemlerde, hepsini yansıtabilme ve bütünlüğü koruyabilme çabası da plan yapımındaki ikinci çaba ve hassasiyet göstermeyi gerektirmiştir. Karşılaşılan ikilemden biri, ana gündemi elde tutarak, muharebelerden ve birliklerin bölgesel yapılanmaları gündeminden bahsedip bahsetmeme konusunda olmuştur. Burada insicamı sağlamak için çok kısa da olsa muharebelerden bahsetme yoluna gidilmiştir. Diğeri de, muharebelerde çok kayıp verilmesi sebebiyle bazen birliklerin lağvedilip perakende birliklerin yeni ad altında yeniden yapılandırılması, başta İstanbul olmak üzere civar vilayetlerden ve cephe içinden devam eden birlik intikallerinin baş döndürücü hızı da zorlayıcı bir ikilemi oluşturmuştur. Müttefik askerlerin eğitimliliği dikkate alındığında, en çok zorlanılan konu ve gündem, muharebeye gelen Anadolu evladının cahil bırakılmasından kaynaklı, askere ait malzemenin neredeyse hiç olmamasıdır.

Bu çalışma Çanakkale muharebelerinde yaşanan gelişmelerin kalbinde yer alan ve pek çok gizemi bünyesinde barındıran karargâhlar hakkında bilgiler vermeyi amaçlamaktadır. Sayfa sınırlaması sebebiyle, bazen ad ve unvan kısıtlamasına gidilmek zorunda kalınmıştır.

\section{5 NCI ORDU'NUN KURULUŞUNA KADAR CEPHEDEKI KARARGÂHLAR}

\section{Çanakkale Boğazı Mücavir Bölgesinde Barış Dönemi Karargâhları}

Birinci Dünya Savaşı arifesinde Osmanlı Devleti'nin mevcut dört ordu müfettişliğinden (ve/ ya komutanlığından) Çanakkale Boğazı ile ilgili sorumlu olan birim, karargâhı İstanbul'da bulunan 1 nci Ordu'dur ${ }^{1}$. Müstahkem Mevki birliklerinin büyük kısmı, barış zamanında var olan ve genelde yer değiştirmeyen birliklerden oluşmuş sabit kuruluşlardır. Çanakkale Müstahkem Mevki Komutanlığı, Boğaz’ın güvenliğini sağlamakla görevli olup, birinci sınıf müstahkem mevkidir. Komutanı, kolordu komutanı yetkisindedir ve karargâhı Çimenlik Kalesi'ndedir². Çanakkale bölgesinde yalnız 9 ncu Tümen ile Jandarma birlikleri bulunmaktadır ${ }^{3}$. Karargâhıyla Tekirdağ'da bulunan 3 ncü Kolordu, Boğaz'ın savunmasıyla görevlidir ${ }^{4}$.

1 ATASE Arşivi, 5/2453, Kls. 3964, Dos. H. 1, F. 1-11.

2 ATASE Arşivi, 6/1666, Kls. 4669, Dos. H-1, F.1-5; ATASE Arşivi, 6/1666, Kls. 4624, Dos. 70, F. 1; ATASE Arşivi, 1/1, Kls. 64, Do3s. 22, F. 1-38.

3 Esat Paşa'nın Çanakkale Anıları, Baha Matbaası, İstanbul 1975, s.21. (EPÇA olarak kısaltılacaktır.)

4 ATASE Arşivi, 6/1666, KIs. 4669, Dos. H-1, F. 1-10; ATASE Arşivi, 6/1666, Kls. 4668, Dos. 72, F. 4. 


\section{Liman von Sanders 1 nci Ordu Müfettişi (Komutanı) ve İstanbul Karargâhı}

Harbiye Nezareti'nin 2 Ağustos 1914 tarihli emriyle, 1 nci Ordu Müfettişliğine Liman von Sanders'in atandığı bildirilmiştir. Çanakkale Boğazı ile ilgili birim, Karargâhı İstanbul'da bulunan 1 nci Ordu'dur 5 .

\section{Harbiye Nazırı \&Başkomutan Vekili Tuğgeneral Enver Paşa ve İstanbul Başkomutanlık Karargâhı}

2 Ağustos 1914'te Harbiye Nezareti'nin üst katındaki Genelkurmay Başkanlığı'nın bulunduğu yerde, 'Karargâh-ı Umumi ve Başkumandanlık Vekâleti' kurularak Enver Paşa'nın göreve başladığı Harbiye Nezareti'nden bildirilmiştir ${ }^{6}$. Karargâh'ta Başkomutan Vekili, yaveri, Genelkurmay Birinci Başkanı, Genelkurmay Birinci Başkan Yardımcısı, Harekât Şubesi Müdürü, Harekât Şubesi Müdür Yardımcısı, İstihbarat Şubesi Müdürü, İstihbarat Şubesi Müdür Yardımcısı, Demiryolu ve Muvasala Şube Müdürü, Demiryolu ve Muvasala Şube Müdür Yardımcısı, Menzil Umum Müfettişi, Sıhhiye Umum Müfettişi göreve başlamıştır?.

\section{3 ncü Kolordu Komutanı Esat Paşa ve Gelibolu Karargâhı}

Karadeniz'deki 29 Ekim'deki Rus limanlarını bombardımanına misilleme olarak, Boğaz önündeki Birleşik Filo, 3 Kasım 1914'te Boğaz giriş tahkimatını bombardımana tabi tutmuş olup, Seddülbahir kalesinde toplam 92 zayiat verilmiştir

1 nci Ordu “Karargâhından alacağı birlikle Gelibolu'ya gelerek Boğaz'ın iki yakasındaki birliklerin tümünün komutasının üstlenmesi" emri üzerine ${ }^{9}$, 3 ncü Kolordu karargâhı 4 Kasım'da bölgeye intikal etmiş olup Kolordu Komutanı Tuğgeneral Esat (Bülkat) Paşa'dır ${ }^{10}$.

3 ncü Kolordu Komutanı, 4 Kasım'da birliklerine gerekli emirleri vermiştir ${ }^{11}$ : Bolayır Mevzii, 7 nci Tümen'e bağlı kalacaktır. 9 ncu Tümen, şimdilik Maydos Müfrezesi adını alarak, Saz Limanı-Seddülbahir arasındaki bölgeden sorumlu olacaklardır.9 ncu Tümen'in Anadolu yakasındaki Menderes Müfrezesi, Kumkale Akçay arasında görevdedir. Karargâhıyla Tekirdağ'da bulunan 8 nci Tümen de Kolordu'nun burada kalan birlikleri ile genel ihtiyat oluşturacaktır. 13 Şubat 1915 tarihi itibariyle 8 nci Ağır Obüs Alayı karargâhıyla Erenköy’de, 2 nci Ağır Obüs Topçu Taburu ve Karargâhı Erenköy’de, 3 nci Ağır Obüs Topçu Taburu ve Karargâhı Karantina Köyü'ndedir ${ }^{12}$.

\section{9 ncu Tümen Komutanı Albay Halil Sami ve Eceabat Karargâhı}

9 ncu Tümenin 26 ncı Piyade Alayı 1 Ekim 1914 tarihli emirle Kirte'ye gönderilmiştir. Karargâhı da Kirte'dedir. Çanakkale'de bulunan 9 ncu Tümen ve karargâhı, Müstahkem Mevkii'nin emriyle 19 Şubat günü Eceabat'a taşınmıştır. (ilgili tümen 1915 Şubat ayının sonuna doğru tekrar Anadolu yakasına alınmış, 18 Mart 1915 zaferi sonrası geri Eceabat'a dönmüştür. $)^{13}$.

\footnotetext{
5 ATASE Arşivi, 5/2453, Kls. 3964, Dos. H. 1, F. 1-11.

6 ATASE Arşivi, 5/2453, Kls. 3964, Dos. H. 1, F. 1-12.

7 İsmet Görgülü, On Yıllık Harbin Kadrosu, Türk Tarih Kurumu Yayınları, Ankara 1993, s.53.

8 ATASE Arşivi, 6/1666, Kls. 4669, Dos. H-3, F. 1-78, 1-79, 1-80;1-83; BOA, DH. EUM. 3. Şb. 2/48.

9 ATASE Arşivi, 5/2453, Kls. 3964, Dos. H-1, F. 1; ATASE Arşivi, 5/2453, Kls. 3964, Dos. H-4, F. 1-31.

10 ATASE Arşivi, 5/2453, Kls. 3964, Dos. H-4, F. 1-31; ATASE Arşivi, 5/2453, Kls. 3964, Dos. H-5, F. 1-2; ATASE Arşivi, 5/2453, Kls. 3964, Dos. H-5, F. 1-4.

11 ATASE Arşivi, 5/2453, Kls. 3964, Dos. H-5, F. 1-4.

12 ATASE Arşivi, 6/1666, Kls. 3964, Dos. H-7, F. 1-15.

13 ATASE Arşivi, 7/9746, Kls. 5338, Dos. H-3, F. 1-7.
} 


\section{9 ncu Tümen Komutanı Yarbay Mustafa Kemal ve Bigalı Karargâhı}

3 ncü Kolordu dâhilinde 19 ncu Tümen Komutanlığı oluşturulmuş ve Mustafa Kemal, 18 Ocak 1915'te atanmış;25 Şubat 1915'te Eceabat'a intikalini tamamlayan 19 ncu Tümen'in harekete hazır olması istenmiştir ${ }^{14}$. 3 ncü Kolordu emrinde, Müstahkem Mevki genel ihtiyatını teşkil edecektir. 19 ncu Tümen bölgeye gelince, 9 ncu Tümen'e yeni savunma düzeni ile ilgili emirler gönderilmiştir ${ }^{15}$.

\section{Müstahkem Mevki Komutanlığı ve Hacıpaşa Çiftliği Karargâhı}

Boğaz girişindeki tabyaların 25 Şubat 1915 bombardımanında tahrip edilmiş olması nedeniyle, 19 Şubat 1915'te Çanakkale Çimenlik kalesindeki faaliyetini sürdüren Müstahkem Mevki Karargâhı, kısa sürede Çanakkale'nin üç kilometre güneybatısındaki Hacıpaşa Çiftliği'ne taşınmıştrt ${ }^{16}$.

3 ncü Kolordu, Bolayır mevziinin sorumluluğunu, karargâhı Bolayır civarında bulunan7 nci Tümen'e vermiş, tümen de gereken düzenleri almıştir ${ }^{17}$.

\section{Anadolu Yakası: Kalvert Çiftliği Karargâhı}

Kalvert Çiftliği Çanakkale'nin yaklaşık 40 kilometre güneyinde ve antik Troya kentine yakın bir çiftliktir. Çeşitli bina ve müştemilata da sahiptir. Çiftliğin binaları karargâh olarak kullanılmıştr. 3 Mart 1915 günü, 126 ncı Piyade Alayı Çanakkale Müstahkem Mevkiinde genel ihtiyatta, 9 ncu Sahra Topçu Alayı ve Karargâhı Kalvert Çiftliği'ndedir ${ }^{18} .64$ ncü Piyade Alayı Yenişehir, Yeniköy ve Üvecik bölgesinde olup, Kumkale Kumburnu güneyine kadar uzanan kıyının savunmasında; 25 nci Alay Erenköy kuzeyi ve Halileli bölgesindedir. 1 nci Taburu, 64 ncü Piyade Alayı ihtiyat olarak Üvecik'tedir ${ }^{19}$.

\section{1 nci Piyade Tümeni ve Ezine Karargâhı}

Balıkesir'den gelerek, Ezine'ye karargâh kuran 11 nci Tümen, bir kısım birlikleriyle Kumburnu-Edremit Körfezi'nde Akçay İskelesi arasındaki Ege Denizi kıyı kesimini gözetleme ve koruma altında bulundurmaktadır. 11 nci Tümen 14 Mart 1915 tarihi itibariyle büyük kısmıyla da Boğaz bölgesi dışından gelebilecek tecavüzlere karşı kullanılmak üzere, Ezine dolaylarında toplu vaziyettedir ${ }^{20}$.

14 BOA, HR. MA,1118/4, Atatürk'ün Bütün Eserleri, C. I (1903-1915), Kaynak Yayınları, İstanbul 2003, s. 281; Uluğ Iğdemir, Atatürk'ün Yaşamı (1881-1918), I, TTK Yayınları, Ankara 1980, s. 37.

15 ATASE Arşivi, 6/8903, Kls. 4836, Dos. H-17, F. 1-44, 1-45, 1-46.

16 ATASE Arşivi, 6/1666, Kls. 4669, Dos. H-12, F. 1-63; 16ncı Kolordu Kurmay Başkan Haydar Mehmet, "16 ncı Kolordu Kurmay Başkanlığına tayin edildim. 5 Mayıs günü geç vakitte saat 22.00'ye doğru, Hacıpaşa Çiftliği'ne vardık. Kurmaylar odasına girdiğimizde..., Fevzi Bey'e haber gönderdim. Kendisi ile görüştükten sonra gizli evrakı verdim. "Haydar Mehmet Alganer, Çanakkale Kara Savaşları Günlüğü, Çanakkale Deniz Müze Komutanlığı Yayınları, Deniz Basımevi, İstanbul 2009, s. 18.

17 ATASE Arşivi, 5/2453, Kls. 3964, Dos. H-8, F. 1-7, 1-16;ATASE Arşivi, 5/2453, Kls. 3964, Dos. H-5, F. 1-16; ATASE Arşivi, 6/2514, KIs. 4831, Dos. H-I, F, 1-5; ATASE Arşivi, 5/2453, Kls. 3964, Dos. H-9, F. 1-24, 1-37.

18 Kurmay Başkanı Mehmet Haydar, "Genelde sahili takip eden bir yolla Kalvert Çiftliğine gidiyoruz. Erenköy'den geçerek saat 14.45'te çiftliğe vardık. Fevzi Bey de burada. Çiftlik adeta şato. Mükemmel. Hatta bazı mobilyaları bile var. Burası önceden Weber Paşa'nın karargâhı olarak kullanılmış....Weber karşıda. Fevzi Bey de Anadolu Bölge Komutanı olmuş(6 Mayıs)...Insan böyle bir çiftliği olsa başka ne ister (18 Mayıs)" Alganer, s.19-21,31

19 ATASE Arşivi; 1/65, Kls. 1964, Dos. 305, F. 1-106-107; ATASE Arşivi, 6/8903, Kls. 4336, Dos. H-10, F. 1-15, 1-17; ATASE Arşivi, 6/1666, Kls. 4669, Dos. H-13, F. 1-1, 1-6.

20 ATASE Arşivi; 6/8903, Kls. 4836, Dos. H-10, F. 1-14, 1-15, 1-17; ATASE Arşivi, 7/1831, Kls. 5774, Dos. H-I, F. 1-110; ATASE Arşivi, 5/2453, Kls. 3964, Dos. H-8, F. 1-23. 


\section{9 ncu Piyade Tümen Alayları ve Karargâhları}

9 ncu Piyade Tümeni'nin Gelibolu yarımadasındaki birlikleri, sağ ve sol yan müfrezeleri adı altında buradaki 19 ncu Tümen Komutanlığı emrindedir ${ }^{21}$. Karargâhıyla Kocadere'de bulunan Sağ Yan Müfrezesi olan 27 nci Piyade Alayı, Koyun Limanı-Değirmenli çizgisiyle, Kabatepe-Eceabat arasındaki kesimin gözetleme ve korunmasından sorumludur ${ }^{22}$. Karargâhıyla Alçıtepe'de bulunan Sol Yan Müfrezesi ile Sağ Yan Müfrezesi güney ara hattyyla, Seddülbahir arasındaki kesimin gözetleme ve korunması görevinde olmak üzere gereken düzeni almıştır ${ }^{23}$.

\section{Başkomutan Vekili Enver Paşa Müstahkem Mevki Karargâhında}

Boğaz savunması için yapılmış olan hazırlıkları denetlemek üzere 18-21 Şubat 1915 tarihleri arasında Çanakkale Müstahkem Mevki karargâhına gelmiş olan Başkomutan Vekili Enver Paşa, incelemelerde bulunmuştur ${ }^{24}$.

\section{Mart 1915 Zaferi ve Sonrası Gelişmeler}

Birleşik Filo'nun 18 Mart 1915 günü uğradığı ağır yenilgi üzerine, Müstahkem Mevkii Komutanlı̆̆ı, Müttefiklerin bu kez kara çıkarması intimaline karşı mevcut savunma düzeniyle ilgili olarak 20 Mart'ta Başkomutanlığa önerisinde bulunmuştur ${ }^{25}$.

Başkomutanlık da 22 Mart'ta bu önerilere cevap olarak ${ }^{26}$ : 9 ncu Tümen'in bir değişikliğe gidilmeden olduğu yerde bırakılması;

19 ncu Tümen'in eskiden olduğu gibi, Saroz Körfezi ve Anadolu kıyılarından yapılabilecek çıkarma girişimlerine karşı kullanılmak üzere 3 ncü Kolordu'ya bağlı olarak Eceabat'ta toplu halde bulunması;

11 nci Tümen konuşlanmasındaki temel düşüncenin de düşmanın Anadolu yakasına asker çıkarma amacının, sadece bu bölgedeki istihkâmların ele geçirilmesi olup, derinlikte bir ilerlemeyi hedeflemeyeceği görüşü dile getirmiştir ${ }^{27}$. Müstahkem Mevki,23 Mart 1915'teMüttefiklerin kara birliklerinin Mondros'ta toplandığının haberinin alındığına dair bilgiyi birlikleriyle paylaşmıştı ${ }^{28}$.

Gelibolu Yarımadası Saz limanından başlayıp Edremit Körfezi'nde Akçay iskelesi ile sona eren Müstahkem Mevki bölgesi savunma düzeni son şeklini almıştır:

Rumeli bölgesinde 9 ncu Piyade Tümeni; Anadolu bölgesinde 11 ncu Piyade Tümeni bölgesinin savunma gücü olacaktır. 19 ncu Piyade Tümeni, Eceabat'ta toplu olarak genel ihtiyat oluşturacaktır ${ }^{29}$. Müstahkem Mevki Komutanlığı 25 Şubat tarihli emriyle 9 ncu Tümen Anadolu yakasının savunulmasıyla görevlendirmiş olup, 27 nci Piyade Alayı Karargâhıyla Kocadere'dedir. 26 ncı Piyade Alayı karargâhı ile Kirte'de bulunmaktadır ${ }^{30}$.

21 ATASE Arşivi, 6/9565, Kls. 4936, Dos. H-5, F. 1-2.

22 ATASE Arşivi, 6/8903, Kls. 4836, Dos. H-10, F. 1-20.

23 ATASE Arşivi, 7/9746, Kls. 5337, Dos. H-4, F. 1-4, 1-10, 1-16.

24 ATASE Arşivi, 6/1666, Kls. 4669, Dos. H-1, F. 1-49, 1-74; BOA, DH, EUM,3.Şb, 4/4.

25 ATASE Arşivi, 6/1666, Kls. 4669, Dos. H-13, F. 1-19; Binbaşı Nihat, Seddülbahir Muharebât, Erkan-ı Harbiye Mektebi Yayınları, İstanbul 1921, s.6.

26 ATASE Arşivi, 6/1666, Kls. 4669, Dos. H-13, F. 1-21.

27 ATASE Arşivi, 6/8903, Kls. 4836, Dos. H-10, F. 1-14, 1-15, 1-17; ATASE Arşivi, 7/1831, Kls. 5774, Dos. H-I, F. 1-110; ATASE Arşivi, 5/2453, Kls. 3964, Dos. H-8, F. 1-23.

28 ATASE Arşivi, 6/1666, Kls. 4669, Dos. H-13, F. 1-22.

29 ATASE Arşivi, 6/1666, Kls. 4669, Dos. H-12, F. 1-85.

30 ATASE Arşivi, 6/8903, Kls. 4836, Dos. H-7, F. 1-53. 
18 Mart 1915 zaferiyle birlikte, 24 Mart'ta Eceabat'a ulaşan 9 ncu Tümen ${ }^{31}$, buradaki 19 ncu Tümen'den Eceabat bölgesi komutanlığını devralmıştı ${ }^{32}$. 9 ncu Tümen, iki alayını Seddülbahir'de, bir alayını Kabatepe-Arıburnu bölgesinde iki grup halinde yerleştirerek son hazırlıkları 31 Mart 1915'e kadar tamamlamıştır ${ }^{33}$.

\section{5 INCI ORDU'NUN KURULUŞU VE CEPHEDEKI KARARGÂHLAR}

\section{Mareşal Liman von Sanders ve 5 nci Ordu Gelibolu Karargâhı}

Kara muharebeleri kaçınılmaz olunca, 1 nci Ordu Komutanı Mareşal Liman von Sanders, (3 ncü ve 15 nci Kolordularla, 5 nci Tümen ve Bağımsız Süvari Tugayı́ndan oluşan) 5 nci Ordu Komutanlığına atanmıştır ${ }^{34}$. Gelibolu'daki Fransız Konsolosluk binası karargâh ve makam olarak tahsis edilmiştir ${ }^{35}$. Göreve başlamak üzere 26 Mart'ta Gelibolu'ya gelen Mareşal, aynı gün Bolayır tarafina hareket etmiştir ${ }^{36}$. Liman von Sanders, Bolayır dışında Gelibolu Yarımadası'nda büyük çıkarma hareketleri beklemediğinden, Çanakkale savunmasını, sadece Saroz ve Anadolu kıyılarına yapılacak çıkarma hesabına göre düzenlemiştir ${ }^{37}$.

Karargâhı Gelibolu'da bulunan 5 nci Ordu'nun iki kolordusundan 3 ncü Kolordu Boğaz'ın Avrupa yakasından, 15 nci Kolordu ise Asya yakasından sorumlu olacaktır.

Bolayır ve kuzeyinde 7 nci Tümen ve 5 nci Tümen (Ordu ihtiyatı) birlikleri; Beşige ve kuzeyinde 11 nci Tümen ve3 ncü Tümen görevlidir ${ }^{38}$.

19 ncu Tümen Kurmay Başkanı Binbaşı İzzeddin": "Bu savaş düzeni 5 nci Ordu karargâhının oluşturulmasından sonra alınmışt. Daha önce sahil gözetlemesi için iki görüş vardı: Birincisi, düşmanı sahile çıkartmamak; ikincisi de düşmana sahile çıktıtan sonra taarruzla karşılık vermek. 3 nci Kolordu tarafindan birinci görüş daha uygun görülmüş, savaş düzeni bu esas üzerine kurulmuştu. 5 nci Ordu'nun bölgeye gelmesinden sonra 3 ncü Kolordu, 9 ncu ve 19 ncu Tümen komuta kadrosu sahili incelemiş (31Mart) ve sonuçta sahilin gözetlenmesine karar verilmiştir."

15 nci Kolordu Harekât Şube Müdürü Binbaşı Nihad da"4, "5 nci Ordu hemen hemen savaş tarihinde bir örneği daha olmayan ve henüz hiç tecrübe edilmemiş bir görev üstlenmiş olduğu için, uygulanacak strateji ile ilgili değişik fikir ve kanaatlerin bulunmasından daha tabii bir şey olamaz. Sahil savunmasında kanaatimizce en iyi hareket şeklinin düşmanın karaya çıkmasına engel olmak olduğunu, ancak bunda başarılı olunamazsa şiddetli taarruzlarla düşmanı durdurmaya ve etrafinı çevirmeye çalışarak, ilerlemesine imkân vermemek gerektiğini, yoksa karaya çıkan bir kuvvetin tekrar denize dökülmesinin çok zor bir iş olduğunu ancak bu savaş sonunda anladık."

31 Yay. Haz. İzzettin Çalışlar - İsmet Görgülü, İzzettin Çalışlar'ın Not Defterinden On Yıllık Savaşın Günlüğü, Güncel Yayıncılık, 3. Baskı, İstanbul 2007, s. 113.

32 ATASE Arşivi, 6/1666, Kls. 4669, Dos. H-13, F. 1-22, 1-23.

33 ATASE Arşivi, 6/1666, Kls. 4669, Dos. H-13, F. 1-19.

34 ATASE Arşivi, 1/1, Kls. 180, Dos. 774, F. 1-5.

35 ATASE Arşivi, 1/1, Kls. 180, Dos. 774, F. 1-6; BOA, HR. SYS, 2109/11.

36 ATASE Arşivi, 5/2453, Kls. 3964, Dos. H-10, F. 1-16.

37 ATASE Arşivi, 4/8749, Kls. 3474, Dos. H-1, F. 1-4.

38 ATASE Arşivi, 6/8056, Kls. 4775, Dos. H-2, F. 1-5, 1-11, 1-13.

39 Çalışlar, s. 114.

40 Binbaşı Nihat, s.12. 


\section{5 nci Ordu Menzil Müfettişliği Karargâhı Akbaş Limanı}

5 nci Ordu'nun ihtiyacını karşılayabilmek için 27 Mart 1915 tarihinde Gelibolu'da 5nci Ordu Menzil Müfettişliği kurulmuştur. Karargâh şubeleri Akbaş olup, teşkilde 'muhafiz', 'telgraf müfrezesi', 'sahra postası' ve 'sahra jandarma takımı' mevcuttur. Menzil alanı Trakya ile Marmara havzasını kapsamaktadır ${ }^{41}$.

5 nci Ordu Menzil Müfettişliği'nin Menzil Sıhhiye Heyeti, Menzil Veteriner Heyeti, Cephane Komutanlığı, Menzil Ulaştırma Komutanlığı, İnşaat Şubesi, Menzil Posta-Telgraf Müdüriyeti, Evrak Kalemi, Menzil Müfettişlik Karargâh Komutanlığı, Muhasebe ve İaşe Subayı gibi idari personelin Personel Dairesi'nce atanmaları, gerekli araç ve gereçlerinin de nerelerden temin edileceği hususunda diğer genel karargâh şubeleri harekete geçirilmiştir ${ }^{42}$.

\section{Kara Muharebelerinde Cephe Karargâhları}

Gelibolu 5 nci Ordu Karargâhı: 5 nci Ordu Komutanı Mareşal Liman von Sanders; 5 nci Ordu Kurmay Başkanı Yarbay Kazım, 5 nci Ordu İdari Başkanı Binbaşı H. Hüsnü; 5 nci Ordu Harekât Şube Müdür Vekili Yüzbaşı Mümtaz; 5 nci Ordu Komutanlığı Kurmay Emir Subayı Teğmen Ekrem Rüştü43;

Gelibolu 3 ncü Kolordu Karargâhı: Gelibolu Yarımada güney ve kuzey bölge sorumlusu 3 ncü Kolordu Komutanı Tuğgeneral Esat; 3 ncü Kolordu Kurmay Başkanı Yarbay Fahrettin; Harekât Şube Müdürü Binbaşı Ohrili Kemal; Kolordu Kurmayı Yüzbaşı Burhanettin; İstihbarat Şube Müdürü Binbaşı Ziya; Harekât Subayı Yüzbaşı Remzi; Karargâh Kurmayı Yüzbaşı Nazmi; Emir Subayı Üsteğmen Baki.

Bolayır (Saros) Bölgesi Karargâhı:5 nci Ordu Komutanı Mareşal Liman von Sanders ile birlikte 5 nci Tümen Komutanı Albay Hasan Basri, 5 nci Tümen Tümen Kurmay Başkanı Binbaşı Mehmet Arif (Ayıcı) ${ }^{44}$.

Anadolu Yakası 15 nci Kolordu Karargâhı ${ }^{45}$, Kalvert Çiftliğï; 15 nci Kolordu Komutanı General Weber ${ }^{47}$; Kurmay Başkanı Alman Yarbay Tuwenay; Harekât Şube Müdürü Yüzbaşı Bursalı Nihat; Karargâhı Hamidiye'de olan 3 ncü Tümen Komutanı Albay Nicolai ve Kurmay Başkanı Yüzbaşı Suphi; Karargâhı Pınarbaşı'nda olan 11 nci Tümen Komutanı Albay Rafet ve Kurmay Başkanı Binbaşı Ali Fehmi'dir.

Kuzey Arıburnu Bölgesi Bigalı Karargâhı"8: 19 ncu intiyat Tümen Komutanı Yarbay Mustafa Kemal ${ }^{49}$; Kurmay Başkanı Binbaşı İzzeddin, 19 ncu Tümen karargâhı, Bigalı Köyü’ndedir. 57 nci Alay karargâhı Bigalı deresinde, 77 nci Alay karargâhı Maltepe’de, 72 nci Alay karargâhı Maydos Yalova yolu doğusunda bulunmaktadır. 23 Nisan'da İngiliz uçağı,

41 ATASE Arşivi, 1/6, Kls. 1129, Dos. 27, F. 2; ATASE Arşivi, 1/1, Kls. 14, Dos. 69, F. 33.

42 ATASE Arşivi, 1/65, Kls. 1886, Dos. 50, F. 1-3.

43 Görgülü, s.64.

44 A.g.e., s.96.

45 Yüzbaşı Celalettin, Kumkale Muharebeleri, Erkan-ı Harbiye Mektebi Yayınları., İstanbul 1921, s.10.

46 Alganer, s.19; Mehmet Haydar, "Bu çiftlik, esasen bir Ingiliz'e aitmiş. Birçok para karşılığında buraya yerleşmiş... Çiftlik intepe bataryası güneyinde bulunduğundan orası bombardıman edildiği zaman sallanıyor. Buraya tarihi Truva harabeleri yakın... (6 Mayıs)".

47 BOA, ì, 1333, Ca. /36; ATASE Arşivi, 4/8749, Kls. 3474, Dos. H-1, F. 1-4.

48 ATASE Arşivi, 6/8903, Kls. 4836, Dos. H-10, F. 1-71.

49 BOA, HR. MA,1118/4; ATASE Arşivi, 1/1666, Kls. 4618, Dos. 43, F. 71; ATASE Arşivi, 6/9665, Kls. 4996, Dos. H-3, F. 1-1. 
Eceabat'ta büyük zayiata sebep olmuştur. Kayıplardan çoğu 72 nci Piyade Alayı́ndan verildiği için, alay 19 ncu Tümen karargâhına alınmıştır ${ }^{50}$.

Güney Seddülbahir Bölgesi Eceabat Karargâhı: 9 ncü Tümen Komutanı Albay Halil Sami; Kurmay Başkanı Binbaşı Hulusi'dir ${ }^{51}$. 27 nci Alay ${ }^{52}$ platonun kuzeyinde, büyük kısmıyla Eceabat çevresinde toplu halde bulunurken, bir kısmıyla da Azmakdere-Çamtepe arasında tertiplenmiş, diğer iki alay da, güneye alınmış olup, bunlardan $26 \mathrm{ncı}$ Alay, Çamtepe'den Kerevizdere'ye kadar uzanan Seddülbahir kıyılar şeridinde yerleştirilmiştir. 25 nci Alay da, ihtiyat olarak Sarafim Çiftliğindedir. 9 ncu Tümen karargâhı, Eceabat iskelesi yöresinde bulunmaktadır ${ }^{53}$.

\section{ANZAK AMFIBI HAREKÂTI}

\section{Kuzey (Arıburnu) Kıyı Muharebeleri}

\section{9 ncu Tümen Bigalı, Kocadere ve Kemalyeri Karargâhları ${ }^{54}$}

27 nci Alay birlikleri, sayılarının azlığına rağmen Anzak’a karşı büyük bir direnç göstermiştir. Şefik Bey'in Alayını Kemalyeri merkezli muharebeye sokması; taarruz geliştikten sonra (sağ kanadın 57 nci Alay tarafindan destekleneceğinden dolayı), merkez ve sol kanatta Kanlısırt-Kırmızısırt ekseninde savunması ve karşı hücuma kalkması, Türk savunmasının kaderini birinci derecede etkilemiştir ${ }^{55}$.

Kurmay Yarbay Mustafa Kemal, Anzak çıkarmasının (Koca)çimendağı silsilesine yöneldiği haberi üzerine, muharebeye karar vermesi ve Conkbayırı'nı Anzak'tan önce, hâkim tepeler silsilesini tutması, devamında karşı hücumla düşmanı geri püskürtmesi, en kayda değer kahramanlıklardan biridir ${ }^{56}$.

Conkbayırı'na uzanan hatt tutmak için gereken kuvveti toparlayamayan Anzak, Balıkçı Damları'ndan Çakaldere'ye uzanan üç buçuk kilometrelik kıyı şeridine yayılmıştır. Türklerin yetişerek hâkim tepeleri tutmasına engel olamamıştı ${ }^{57}$.

Mustafa Kemal'in karargâhı 25 Nisan gününe kadar Bigalı'dadır. 26 Nisan'da Kocadere batı sırtlarında, 26 Nisan gecesi Kocadere köyünde kurulmuştur ${ }^{58} .17$ Mayıs'a kadar cephedeki ilk karargâhı Kemalyeri olmuştur ${ }^{59}$.

50 ATASE Arşivi, 6/8903, Kls. 4836, Dos. H-10, F. 1-68.

51 Görgülü, s. 64

52 Ahmet Mucib Kemalyeri Çanakkale Ruhu Nasıl Doğdu ve Azerbaycan Savaşı 1917-1918, Baha Matbaası, İstanbul 1972, s.18; 27 nci Alay 12 nci Bölük Komutanı Vekili Teğmen'dir.

53 Aynı yer.

54 ATASE Atatürk Arşivi, Dos. 6-35, Def. 8, F. 1-11, 1-12, 1-15; Ruşen Eşref (Ünaydın), "Mülakatlar VI Mustafa Kemal Paşa: Birinci Safha", Çanakkale 5/8 Mart 1331/1915, Yeni Mecmua, Nüsha-i Fevkalade, Hilal Matbaası, İstanbul 1334/1918, s. 348; Çalışlar, s. 115.

55 ATASE Arşivi, 6/8903, Kls. 4836, Dos. H-10, F. 1-71, 1-73; ATASE Arşivi, 6/8903, Kls.4836, Dos.H-11, F. 1-19; Şefik Aker, Çanakkale - Arıburnu Savaşları ve 27 nci Alay, İstanbul 1935, s. 21, 59.

56 ATASE Atatürk Arşivi, Dos. 6-35, Def. 8, F. 1-11, 1-12, 1-13, 1-15, 18, 1-25, 1-26, 1-32; ATASEArşivi,6/8903, Kls. 4836, Dos.H-10, F. 1-72; ATASE Arşivi, 4/8747, Kls. 3474, Dos. H-4, F. 1-8, 1-10.

57 Cecil Faber Aspinall-Oglander, Çev. Tahir Tunay, Çanakkale Gelibolu Askeri Harekât, C. I, Askeri Matbaa, İstanbul 1939, s.328.

58 Çalışlar s.115.

59 Çalışlar, s.118;ATASE Atatürk Arşivi, Dos. 6-35, Def. 10, F. 1-7; Mustafa Kemal, "3 ncü Kolordu Komutanı (Esat) Paşa hazretleri ahvali yakından görmek için ilk defa olarak bugün bulunduğum Kemalyeri'ne gelmişlerdi." (Yay. Haz: Uluğ İ̆demir), Arıburnu Muharebeleri Raporu, Türk Tarih Kurumu Yayınları, Ankara,1990, s.87.(AMR olarak kısaltllacaktr.); Kannengiesser, "Kemalyeri'ne giden dik yamacı tirmandık. Kendimi 5 nci Tümen Komutanı olarak takdim edip,..."Han Kannengiesser, Çanakkale Cehenneminde 500 Alman, Arcan Yayınları, İstanbul 2010, s.106. 
Cephede karargâh yeri bulma konusunda, 3 ncü Kolordu Kurmay Başkanı Fahreddin, "Mustafa Kemal ile Kurmay Başkanı Izzeddin bir sel yarıntısında ayaklı bir dürbünle düşman hatlarını gözetliyorlardı... Ihtiyaçlarını sordum. Ayrılıyorduk. "Karargâhınız hep burada mı kalacaktır? Burasının adı nedir? ... Mustafa Kemal biraz düşündü: "Evet burada kalacağız. Ama sel yarıntılarının adı mı olur?" (Bunları derken gülümsüyordu.) "Olur... olur... Mesela 'Kemalyeri' olur ${ }^{601}$ dediğini aktarır.

5 nci Tümen Kurmay Başkanı Mehmet Haydar, "Kemalyeri'ne doğru yola çıktım. Jandarma askerimiz yolu gösteriyor. Kemalyeri'ne vardık. Ordugâh bir vadi altında, biraz daha yukarı çıkıyoruz. Burası Mustafa Kemal Bey'in karargâhı imiş. Zamanla ismi Kemalyeri kalmış (16 Haziran) ${ }^{61 "}$.

27 Nisan günü Türk komuta kademesinin elinde iki seçenek vardı. Bunlardan, yeni gelen ihtiyatlarla başlatılacak bir hücumla karşıdaki kritik tepeleri almak yönündeki Mustafa Kemal taarruz etme fikri kabul görmüştür ${ }^{62}$.

\section{5 nci Ordu Yeni Karargâhı: Bayır Köyü}

2 Mayıs 1915 günü Gelibolu'da bombardıman sebebiyle yangın çıkmıştır. Erzak ve cephane depoları Akbaş, Nara ve Lâpseki'ye nakledilmiştir. Hastane isabet almış hasta ve yaralılar Tekirdağ'a nakledilmiştir. 5 nci Ordu Karargâhı da Gelibolu'nun 10 kilometre kadar güneyindeki Bayır Köyü'ne yer değiştirmiştir ${ }^{63}$.

Gelibolu'da bulunan Ordu Menzil Müfettişliği, Lâpseki'ye alınmış ve yalnız bir 'Nokta Komutanlığı' bırakılmıştır. Tonajlı birinci sınıf ikmal maddesi stokları Akbaş, Nara, Lâpseki iskelelerine dağıtıımıştır. Bu durum, ordu ikmal kanalının bir noktada sıkışıp daralan akışını ileriye doğru açmak çok isabetli olmuştur ${ }^{64}$.

\section{Mayıs Ayı Muharebeleri}

1 Mayıs günü ve gecesi yapılan taarruzlar, tahkimatını iyileştirmiş, yerleşmiş, sayıca ve ateş gücü üstün Anzak’a karşı, çok geniş bir hatta başarılı olma şansı yoktur. Aynı zamanda muharebeye katılan 20.000 kişilik birliğin kaybı da ağırdır ${ }^{65}$.

Kuzey ve Güney'de 3-4 Mayıs günlerinde verilen 6.000 kişilik büyük zayiat; ağır topçu desteğinin yokluğu, hafif topçunun cephane azlı̆̆ı, askerlerin gece eğitimi olmaması, kuvvetlerin parça parça kullanılması gibi hatalar zincirinin ortak ürünüdür. Türk birliklerinin her iki cephede birden peş peşe taarruzlara kaldırılması, bunlardan birinin ağırlık merkezi olarak belirlenmeyişi ve top atışlarının bir notada yoğunlaştırılamaması da, bu taarruzların sonuçsuz kalmasının sebeplerindendir ${ }^{66}$.

60 Fahrettin Altay, On Yıl Savaş ve Sonrası, Eylem Yay., İstanbul 2008, s.88; Çalışlar, s. 118.

61 Alganer, s.58.

62 ATASE Atatürk Arşivi, Dos. 6-35, Def. 9, F. 1-2, 1-4, 1-5;27 Nisan günü ve gecesi harekâtının meydana getirdiği mevzi hatları, çok küçük ve dalgalanmalar hariç, bütün savaş devamınca bir daha değişmeyecektir. Taraflar toprağa gömülecek, her gün kısa ve kanlı döğüşlerle mevzi savaşları başlayacaktır. Kuzey kanat operasyonu ve Anafartalar amfibi harekât gibi yeni gelişmelere rağmen Arıburnu'ndaki bu mevziler aynı durumda kalacak, Anzak 8,5 aylık işgalden sonra yine aynı mevzilerden yüz geri olup çekilmişlerdir.

63 ATASE Arşivi, No. 4/8747, Kls. 3474, Dos. H-4, F. 1-25.

64 Genelkurmay, Çanakkale Cephesi 2 nci Kitap, s. 161, 361.

65 ATASE Arşivi, 4/8747, Kls. 3474, Dos. H-4, F. 1-18; ATASE Atatürk Arşivi, Dos. 6-35, Def. 10, F. 1-6.

66 ATASE Atatürk Arşivi, Dos. 6-35, Def. 10, F. 1-6, 1-7, 1-13; ATASE Arşivi, 4/8747, KIs. 3474, Dos. H-4, F. $1-8$. 
19 Mayıs taarruzu, tahkimatını iyice güçlendirmiş ve mevzilerini derinleştirmiş Anzak’a karşı girişilen, kötü planlanmış ve aynı derecede kötü uygulanmış bir harekâttır ${ }^{67}$. Çok dar bir alanda, net olmayan emir ve hedeflerle, bölgeyi az bilen 2 nci Tümen, baskın etkisinin tamamen ortadan kalktığı anlarda ateşe sürülmüş; hücum gün ağardıktan sonra da tekrarlatılmıştır68. Türk birlikleri 10.000 zayiat vermiş olup 4000 kadarı şehittir ${ }^{69}$.

\section{Kol Düzeninden Kuvvet Komutanlığına}

Kuzey bölgesinde amfibi harekâtı başladığı 25 Nisan 1915 gününden itibaren 5 Mayıs'a kadar Arıburnu'ndaki bütün birliklere 19 ncu Tümen Komutanı Mustafa Kemal komuta etmiştir. 19 ncu Tümenin kendi 57 nci, 72 nci, 77 nci Alaylarına 27 nci, 33 ncü, 64 ncü Alaylar da ilave edilmiştir. 1 Mayıs Türk taarruzuna 13 ncü, 14 ncü, 15 nci ve 125 nci Alaylar da iştirak etmiştir ${ }^{70}$. Kendisine özgü tarz gösteren Arıburnu muharebeleri, 19 ncu Tümen Komutanlığının mihverinde cereyan etmiştir. Karargâhı olmayan Kol Komutanlıkları idari işlemleri yetişememişlerdir. Haberleşme hizmetleri noksan, ikmal hizmetleri tıkalı ve tümen seviyesindeki bir karargâh için cephe kuvvetinin ihtiyaçlarına yetişebilmek çok zor olmuştur ${ }^{71}$.

Savunma dört grup halinde düzenlenmiş, bölgeler sınırlandırılmış, grup teşkilât kurulmuş ve atamalar şu şekilde yapılmıştır: Anadolu, Güney, Kuzey, Saros Grubu.

3 ncü Kolordu Komutanı Esat Paşa, yeni Kuzey Grubu Komutanıdır². Kuzey Grubu emrindeki birlikler: Kuzey kanatta 19 ncu, merkezde $5 \mathrm{nci}^{73}$ ve güney kanatta $16 \mathrm{ncı}$ Tümenler, 3 ncü, 7 nci, 9 ncu ve 15 nci Tümenlerden bazı birliklerdir.

\section{5 nci Ordu Yeni Karargâhı: Yalova Köyü ${ }^{74}$}

5 nci Ordu Karargâhı, 10 Mayıs 1915 günü, Gelibolu'dan Bigalı köyünün beş kilometre kadar kuzeydoğusundaki Yalova Köyü dolayına yer değiştirmiştir ${ }^{75}$. 5 nci Ordu Menzil Müfettişliği de, hizmetleri daha yakından kontrol edebilmek için, 9 Mayıs 1915'te Akbaş bölgesine taşınmıştır.

Bulgaristan'da yayın yapan Otro gazetesi muhabir ve yazarı Madam Wanda Zembrzuska'dan Yalova'daki 5 nci Ordu karargâhını ziyaret eder ve "Liman Paşa bizi çam ağaçları altındaki köşkü önünde kabul etti. Paşa bana: "Burada ilk defa olarak kadın görüyorum. Siz de siper ve ta'biyeleri ziyaret etmek mi istiyorsunuz?" "Evet, Paşam. "Kork-

67 ATASE Arşivi, 4-8747, Kls. 3174, Dos. H-4, F, 1-22; ATASE Arşivi, 4/8747, Kls. 3474, Dos. H-5, F.2-3, 2-5, 2-11, 2-13, 2-20, 2-30, 2-35; ATASE Arşivi, 4/8717, Kls. 3171, Dos. H-6, F. 2-4;ATASE Arşivi, 4/8747, Kls. 3474, Dos. H-6, F.3, 3-15,3-16,3-24, 3-27, 3-30.

68 ATASE Arşivi, 5/2453,Kls.3964, Dos. H-22, F. 1-12; ATASE Arşivi, No. 5/2453, Kls. 3964, Dos. H-23, F. 1-1, 1-7, 1-11.

69 ATASE Arşivi, 4/8749, KIs. 3434, Dos. H-14, F. 5-38.

70 Görgülü, s. $65,66$.

71 Genelkurmay, Çanakkale Cephesi 2 nci Kitap, s. 173.

72 O ana kadar tüm cephenin komutanı olan Esat Paşa, "4 Mayıs 1915...Ordu Komutanı Liman von Sanders'in 4 Mayıs 1915'te karargâhına geldikten sonra..." -cephede fazla kalmasa da- Weber Paşa'nın Güney Grubu Komutanı olduktan sonra -de facto- bu gelişme olmuştur. Esat Paşa arttk sadece Kuzey Grubu Komutanı'dır; EPÇA, s. 556.

73 ATASE Arşivi, 5/2453, Kls. 3964, Dos. H-61, F. 1-27.

74 BOA, HR. MA, 1143/72, 1144/20, 1144/5 (22 Eylül 1915)

75 Mehmet Haydar, "Burası birçok toplanma hattı arasında bir yer. Çamlar altında çadırlar kurulmuş. Dün düşman burayı bulup bombardıman etmiş. Çok fazla zarar yok ama epey bozulmuş. Yine de sessizlik sağlanmış. (14 Haziran)." Alganer, s.55. 
muyor musunuz?"....Programı şu şekilde hazırladık: Önce Miralay Mustafa Kemal Beysin kumandası altında Anafartalar Cephesiıni ziyaret edecektik... Liman Paşaının Erkânı Harbiye Heyeti tamamıyla Alman subayından oluşmaktadır. Ancak Almanyaıda tahsilini tamamlayarak Almancaya vakıf Türk subaylar da heyete ATASE sıfatıyla katılmaktadır. Bu subaylar, Alman subaylar ile Almanca bilmeyen Türk subayları arasında bağlantıyı kuruyorlar... Gelibolu'daki askeri hareketin nazımı Almanlar, yani planlama kısmını Almanlar tertip ediyor, uygulamayı ise Türkler ifa ediyorlar. Karargâh'ta Alman subayı aşağı yukarı on kişiden ibarettir. Bundan başka İstanbul vesair mevkilerde de bazı Alman subayı daha vardır ki bunlar, ya kurmay veya askeri uzman sınıfından....Almanlık ile Türklük arasındaki kültürel fark dikkate alındığı takdirde Karargâh'ta Almanlar ile Türklerin ayrı birer karargâh oluşturmalarının sebebi pek kolaylıkla anlaşılır. Onlar ayrı ayrı olmakla daha rahat ve daha serbesttirler."

\section{Başkomutan Vekili Enver Paşa Cephede}

Başkomutan Vekili 11 Mayıs günü, karargâh kademesiyle Gelibolu'ya 5 nci Ordu Karargâhı'na gelmiş ve brifinge katılmıştır. Kuzeyden başlayarak bütün muharebeyi gözden geçirmiştir ${ }^{76}$. 19 ncu Tümen Kurmay Başkanı İzeddin,"11 Mayıs 1915 günü öğleden sonra Başkomutan Vekili Enver Paşa, Kolordu Komutanı Esat Paşa, Ordu Erkânıharbiye Reisi Kâzım Bey, Kolordu Erkânıharbiye Reisi Fahri (Altay) Bey, İsmet (Inönü Bey vesaire, (Kemalyeri) karargâhına geldiler. Mevki, vaziyet-i harbiye hakkında malûmat edindiler, bir saat sonra avdet eylediler ${ }^{77}$." Haydar Mehmet ${ }^{78}$, "Intepe'ye Harbiye Nazırı geldiğinden komutan oraya gitti. Karşıdaki durumdan Harbiye Nazırı oldukça memnun imiş. (12 Mayıs)"

19 Mayıs'ta Anzak'ı denize dökmek için dört tümenle bir taarruz yapma kararı, 11 Mayıs'ta 5 nci Ordu Karargâhı'nı ziyaret ettiği zaman Enver Paşa ile Liman Paşa arasındaki gizli bir görüşme sırasında alınmıştır. Çanakkale'ye geçerek Müstahkem Mevki Komutanlığını da ziyaret ettikten sonra 12 Mayıs günü tekrar İstanbul’a dönmüştür ${ }^{79}$.

\section{Kuzey Grubu Komutanlığı Karargâhı: Kemalyeri}

17 Mayıs'ta Kuzey Grubu Komutanı Esat Paşa, karargâhını Maltepe ${ }^{80}$ 'den kaldırarak Kemalyeri'ne yanaştırmıştır ${ }^{81} .19$ ncu Tümen Komutanı Mustafa Kemal de, kendi adı ile tanınan bu mevkiden 180 Rakımlı Tepe'ye yer değiştirmiştir ${ }^{82}$.

Esat Paşa, 5 nci Ordu Komutanı'nın karargâhı ilk ziyareti ile ilgili olarak"83, "5 nci Ordu Komutanı Liman von Sanders'in 15 Temmuz'da (Kemalyeri) karargâha gelmiş ve gayet iltifat edici çehre ile yarım saat kalmıştır."

76 ATASE Arşivi, 4/8747, Kls. 3474, Dos. H-5, F. 2-20.

77 Çalışlar, s.118.

78 Alganer, s.25.

79 ATASE Arşivi, 4/8749, Kls. 3474, Dos. H-5, F.2-19; ATASE Arşivi, 4/8747, Kls. 3474, Dos. H-5, F. 2-30; ATASEArşivi,4/8747, Kls.3474, Dos. H-6,F. 3-24;Sanders, s. 72-73.

801 Mayıs günü sabahı beş düşman uçağı Maltepe'deki 3 ncü Kolordu karargâhını bombalamıştır. ATASE Arşivi, 4/8748, Kls. 3447, Dos. H-4, F. 1-25; ATASE Arşivi, 5/2453,Kls.3964, Dos. H-22, F. 1-12.

81 ATASEArşivi,4/8747,Kls.3474, Dos. H-6,F. 3-24.

82 ATASE Arşivi, 5/2453, Kls. 3964, Dos. H-22, F. 1-12; Çalışlar, s. 120;Liman von Sanders'in 18 Temmuz'da karargâha tekrar gelmiş ve Esat Paşa'nın 'ferik'liğini müjdelemiştir. EPÇA, s. 670.

83 EPÇA, s.700. 


\section{9 ncu Tümen ve Düztepe Karargâhı}

Esat Paşa, "17 Mayıs 1915 günü, 19 ncu Tümen Komutanı Mustafa Kemal daha kuzeyde kendisinin uygun göreceği bir yere nakilde serbest bıraktım. Tümeninin arkasına gider gitmez, dürbünüyle araştırarak Kemalyeri'nden daha iyi bir yer seçmiş, az zaman zarfinda yer altında iş ve şube odalarıla, misafir odası olan bir mekân oluşturmuş ve hele misafir odasının zeminini duvarlarını ve hatta tavanını kapatmış ve her yeri tefriş etmiş ${ }^{84 . "}$

Kurmay Başkan İzzeddin, "4 Haziran 1915 günü öğleden sonra karargâhı Düztepe’ye naklettik. ${ }^{85 " ~ " S a a t ~ 17.30 ' d a ~ K o m u t a n ~ B e y ~(M u s t a f a ~ K e m a l) ' l e ~ b i r l i k t e ~ y e n i ~ h a z ı r l a n a n ~}$ karargâh mahalline gittik (20 Haziran 1915) ${ }^{86}$.

29 Haziran günü Başkomutan Vekili Enver Paşa, Şehzade Faruk Efendi ile birlikte gelen İstanbul mebusu Hüseyin Cahit (Yalçın) Bey ${ }^{87}$, "Türk ordusu, Çanakkale dere ve tepelerini çok büyük bir köstebek yuvası haline getirmiştir. Bu örtülü yollar içinde kilometrelerce gidiliyordu. Bazı yerleri dolaştıktan sonra Arıburnu'na gelmişiz... Mustafa Kemal, sade savaş kılığı içinde ve enerjik bir yüz.... Komutanlar görüşürken genç subaylar beni siperin içinde indirdiler. Bir noktada saplanmış bir dürbünden siperlerin dışını, düşman hatlarını ta yan başımızda gördük... Yeniden toplant yerine döndügümüz zaman, Mustafa Kemal bize ayran çıkarttırdı. Nerede olduğunu görmediğimiz bir müzik takımı Carmen operetinden bir parça çaldı."

\section{İki Günlük Kumkale Amfibi Harekâtı}

Kumkale'de, muharebelerin -Türk askerlerinin fedakârlıkları dışında kalan- her noktasında, problem ve yanlışlıklarla doludur. Temel askeri kurallarla uyuşmaması yüzünden zayiat yüzde 50 gibi korkunç hal almıştır ${ }^{88}$. Burada Tümen'den başlayan ve aşağıya doğru inen hatalar zinciri mevcuttur.

Kumkale savunmasında, taktik yönüyle dört noktada zafiyet oluşmuştur: tümenden ast kademelere kadar yansıyan gereksiz telaş, sevk ve idare dağınıklığı; karşı hücum için parça parça sevk edilen birliklerin hedeflerine çok gecikerek yetişmiş olmaları; gece taarruzlarının hazılıksız ve sıkışık düzende yapılması; keşif ve haberleşme hizmetlerindeki yetersizliklerdir ${ }^{29}$. Sınırlı ölçüde ve aldatıcı amaçla yapılan ve burada sona eren iki günlük bir harekâttrr.15 nci Kolordu'nun affedilemez zafiyeti olduğu da ortadadır. Komuta heyeti tarafindan geri çekilmenin ancak 10 saat sonra, anlaşılması, bölgedeki savunma skandalının mahiyeti hakkında tek başına bir fikir vermektedir ${ }^{90}$.

Fransızlar, iki tümeni yerlerinde 'tespit etmeyi başarmıştır. Bu sebeple Anadolu yakasındaki Türk kuvvetlerinin intikali gecikmiştir. Türk topçusunun, Seddülbahir ve civarına çıkarma yapacak askerleri rahatsız etmesine engel olmuştur ${ }^{91}$.

84 EPÇA, s. 583.

85 Çalışlar, s.125.

86 A.g.e., s. 128.

87 Hüseyin Cahit Yalçın, Siyasi Anılar, Türkiye İş Bankası Yayınları, İstanbul 1976, s. 225.

88 ATASE Arşivi, 4/8749, Kls. 3474, Dos. H-1, F. 1-4, 1-5; ATASE Arşivi, 6/8056, Kls. 4775, Dos. H-2, F. 1-1, 1-2; ATASE Arşivi, 4/8749, Kls. 3474, Dos. H-2, F. 2-8, 2-17, 2-18, 2-25; ATASE Arşivi, 6/8056, Kls. 4775, Dos. H-2, F. 1-1, 1-2, 1-3, 1-5, 1-6, 1-7, 1-8, 1-9, 1-10, 1-11, 1-12, 1-15.

89 Genelkurmay, Çanakkale Cephesi 2 nci Kitap, s. 90.

90 BOA, HR. SYS, 2323/1; BOA, HR. SYS. 2110/3; Vedel, s.76;

91 Fahri Belen, Birinci Dünya Harbinde Türk Harbi 1915 Yılı Hareketleri, Kara Kuvvetleri Komutanlığı Yayınları, Genelkurmay Basımevi, Ankara 1963, s.36;Aspinall-Oglander, s. 249,251, 256, 263, 264; Rene' Desmazes, Çanakkale Seferi, s. 57, 58. 


\section{(Şehzade) Ömer Faruk Efendi, Enver Paşa ve Maiyeti Cephede}

29 Haziran günü Başkomutan Vekili Enver Paşa, Şehzade Faruk Efendi, İstanbul mebusu Hüseyin Cahit (Yalçın) Bey ile birlikte19 ncu Tümen karargâhına gittiklerinden bahsettikten sonra Esat Paşa92, "Efendi (Şehzade Faruk), halılarla bezenmiş olan Mustafa Kemal'in kabul odasına girdiği vakit, yorgunluktan bitap idi. Kendisine bayılır gibi bir hal geldi. Su ve müteakiben Mustafa Kemal Bey'in hazırlattğı limonata içilerek kendine geldi."

Kurmay Başkanı Izzeddin"93,"29 Haziran 1915 günü. Başkomutan Vekili (Enver Paşa) ve maiyetinin Ordu Karargâhına geldiğini istihbar ettik... Öğleden sonra Kemalyeri'ne gittim. Başkomutan vekili de maiyetiyle beraber Kemalyeri'ne geldiler. Tebessüm ederek elimi sıkt. Kemalyeri'nden sonra da bizim karargâha geldiler. Enver Paşa, (Şehzade) Ömer Faruk Efendi, Cahit Bey, İsmet Bey, Kâzım Bey, diğer yaverler, iki saat kadar bizde kaldılar. Kemalyeri'nden bize kadar yaya geldiler."

Veliaht Yusuf İzzeddin Efendi Cephede

19 Temmuz günü Veliaht Yusuf İzzeddin Efendi cepheyi ziyarete gelmiştir. Veliaht ve maiyeti otomobille Kemalyeri'ndeki karargâha giderken bombardımana hedef olmuşlar ve konvoy yarım saat kadar geç ulaşılmıştır ${ }^{94}$. Esat Paşa ${ }^{95}$, "Sinirlenen Veliahd'a, 'Bir Veliahdımız var. Bütün Ordu muhafaza etmek mecburiyet ve mesuliyetindedir' deyince, biraz sükûnet buldu. Saat 14.10'da Kocadere'yi geçtiğimizde obüs atışı başlayınca, 10 dakika da yolda bekledik, sonra yolumuza devam ettik." Veliaht Yusuf İzzeddin Efendi, Veliaht Yusuf İzzeddin Efendi daha sonra Ordu karargâhında onuruna verilen bir ziyafete katılmış ve aynı gece maiyeti ile birlikte Ordu karargâhında geçirmiştir ${ }^{96}$.

Kurmay Başkanı İzzeddin", "Saat 04.00'de Kumandan Bey'le Veliaht Yusuf Efendi'yi karşılamak üzere Kemalyeri'ne gittik. Tümen ve Bölge Kumandanlarıla Kurmaylar mevcuttu. Uçak/obüs bombardımanı yüzünden ziyaret iki saat ertelendi. Saat 14.00 sularında Veliaht teşrif etti. Karşılama merasimi yapıldı, bir saat kadar oturdular. Aynı merasimle döndüler."

\section{GÜNEY CEPHEDE AMFIBi HAREKÂTI}

\section{Seddülbahir Kıyı Muharebeleri98}

Güneydeki amfibi harekâtta, Türk savunmasının durumu aşırı derecede kritiktir. Birliklerde makineli tüfek ve topçu desteği olmaması, büyük sıkıntılar doğuracaktır.

Erken saatlerde komutansız alan merkezi atı̧ kontrol sistemi yok olmuş; piyade tabur komutanlarına bağlanan bazı bataryalar da pasif kalmıştı ${ }^{99}$. İtiyat konumundaki ve 25 nci Alay'ın muharebeye geç sokulmasında, hem 9 ncu Tümen'in hem alay komutanının ihmali söz konusudur ${ }^{100}$.

92 EPÇA, s. 674.

93 Çalışlar, s.130.

94 EPÇA, s. 676.

95 EPÇA, s. 677.

96 Aynı yer.

97 Çalışlar, s.134-135.

98 ATASE Arşivi, 7/9592, Dosya H-I-3; ATASE Arşivi, 6/8903, Kls. 4836, Dos. H-11, F. 1 -18, 1-22, 1-23, 1-24, 26;Binbaşı Mahmut Sabri, Seddülbahir'in Illk Şanlı Müdafaası, Yeni Anadolu Basımevi, Konya 1933, s. 8-15; Aspinall-Oglander, s. 223, 239, 249, 251, 253, 256, 263, 265, 268, 278.

99 ATASE, 7/9746, Kls. 5337, Dos. H-I, F. 1-1, 1-2, 1-3, 1-4; Mahmut Sabri, s.19.

100 ATASE Arşivi, 7/9746, Kls. 5337, Dos. H-6, F. 1-2, 13 
Bu durum, kıyıdan gelişmekte olan İngiliz harekâtını sağ kanatta, Pınariçi Koyu ekseninde tamamen serbest bırakmış; Müttefiklere -kullanamadıkları- büyük bir firsat doğmuştur ${ }^{101}$.

Eskihisarlık çıkarmasında, İntepe topçusunun savunmaya yardım edememesi, zayıf kıyı savunmasının ezilmesine neden olmuş; İngilizlerin kendi sağ kanatlarından saldırmamaları da Türk savunmasını, erken bir yıkımdan korumuştur ${ }^{102}$.

3 ncü Tabur, üstün Müttefiklere karşı 24 saati aşan bir direniş göstererek, İngilizlere Alçıtepe-Kilitbahir platosu yolunu tıkamıştır ${ }^{103}$.

Gemileri istenen bombardıman etkisi sağlayamadığı gibi, mermiler, hendeğe veya derin sipere girmiş Türkler üzerinde etkili olamamış; Türkler mevzilerine girerek düşmanı karşılamaya hazırlanmışlardır ${ }^{104}$.

26 ve 27 Nisan günleri, Çanakkale muharebelerinin en krizli zamanlarından biridir. Ordu ihtiyatlarının bölgeye sevkinde ciddi bir gecikme yaşanmıştır. Komuta kademesinin sevk ve idaredeki zaafları, iki alayı büyük zayiata uğratmıştır.9 ncu Tümen Komutanının savunma hattını daha da geriye alma emri, büyük bir tehlike doğurmuştur ${ }^{105}$. 3 ncü Kolordu Komutanlığı bu teklifi reddetmiş ve İngilizlerin de ileri harekâta başlamaması nedeniyle kriz atlatılmıştir ${ }^{106}$.

Birinci Kirte Muharebesi'nde, 20 nci Alay, 26 ncı Alay ve 3 ncü Tabur Komutanları yüksek performans ve gayret göstererek, dengenin değişmesine engel olmuşlardır ${ }^{107}$.

Askerlerin hâlâ organize edilememesi, sevk ve idaredeki yetersizlik, birliklerin parça parça ve bağlı oldukları birliklerden alınarak sevk edilmesi ciddi problemlere yol açmıştr. 19ncu Alay'ın muharebeye girişiminin geciktirilmiş olması yüzünden oluşan tehlikeli durum, Binbaşı Mahmut Sabri'nin şahsi gayretiyle önlenebilmiştir ${ }^{108}$.

1-2 Mayıs ve 3-4 Mayıs'ta yapılan gece taarruzları, Güney muharebelerinin en karanlık sayfalarından birini oluşturur. Ordu ve Bölge Komutanlıklarının yanlış karar ve uygulamaları yüzünden pek çok şehit verilmiştir ${ }^{109}$.

Liman von Sanders, 5 nci Tümen Komutanı von Sodenstern'i Güney Bölgesi Komutanı olarak görevlendirmiştir ${ }^{110}$. 5nci Ordu'nun bölgedeki savunma anlayışı, bir iki gün içinde kuvvetli intiyatlarla İngilizler yerleşmeden denize dökülmesi üzerine kuruludur. Hâlbuki Müttefikler'in bölgedeki kuvveti 30.000 askeri aşmıştr. İçeriye doğru iki kilometre alana yerleşen Müttefikler, kuvvetli tahkimat yapmış; tel örgüler çekmiş ve çapraz ateşle etkili olacak şekilde makineli tüfeklerini yerleştirmiştir ${ }^{111}$.

101 ATASE Arşivi, 7/9746, Kls. 5337, Dos. H-I, F. 1-3, 1-4, 1-5.

102 Belen, s.63.

103 ATASE Arşivi, 7/9746, Kls. 5337, Dos. H-5, F. 1-1, 1-23, 1-26, 1-27, 1-28, 1-29.

104 ATASE Arşivi, 6/8903, Kls. 4836, Dos. H-10, F. 1-78, 1-79, 1-80, 1-81, 1-83.

105 ATASE Arşivi, No. 6/8903, Kls. 4836, Dos. H-10, F. 1-78; ATASE Arşivi, No. 6/8903, Kls. 4836, Dos. H-11, F. 1-23.

106 ATASE Arşivi, No. 6/8903, Kls. 4836, Dos. H-10, F. 1-79; ATASE Arşivi, 6/8903, Kls. 4836, Dos. H-11, F. 1-24.

107 Aspinall-Oglander, s. 316, 328; ATASE Arşivi, 6/8903, Kls. 4836, Dos. H-10. F. 1-82, 1-84, 185.

108 ATASE Arşivi, 6/8903, Kls. 4836, Dos. H-11, F. 1-27, 1-28.

109 ATASE Arşivi, 6/8903, Kls. 4836, Dos. H-11, F. 1-29, 1-31, 1-33; ATASE Arşivi, 5/2453, Kls. 3964, Dos. H-17, F. 1-14, 1-25; ATASE Arşivi, 4/8747, Kls. 3474, Dos. H-5, F. 2-2, 2-4.

110 ATASE Arşivi, 6/8903, Kls. 4836, Dos. H-10, Fih. 1-86, 1-89.

111 ATASE Arşivi, 5/2453, Kls. 3964, Dos. H-15, F. 1-21, 1-31, 1-33. 
Güney Bölgesi Komutanlığınca yeterli keşif yapılamamış, birliklerdeki karışıklık giderilememiştir. Türklerin kuvvetli topçu desteği olmayışı, donanmanın coğrafyadaki önemli avantajı yüzünden, hücumların gece yapılmasına karar verilmiştir. Hâlbuki birliklerin büyük çapta gece taarruzları için eğitimleri yoktur. Ağırlık merkezleri oluşturulmamış olduğu için baskın etkisi de kaybolmuştur ${ }^{112}$.

3 Mayıs akşamı taze kuvvet olarak gelen 15 nci Tümen, parça parça ileri sürülmüş fakat tümenin ne yapacağı belli olmadığı gibi, yazılı bir emir dahi verilememiştir. Sadece Tümen Komutanı ve taburlar, şifahi olarak bilgilendirilmiştir ${ }^{113}$.

3 Mayıs gecesi Bölge Komutanı ve Üç Tepeler Mevkii'ndeki karargâhından ayrıımış ve ileri hatlara doğru yaklaşarak, her iki kanatta devam eden muharebelerin bütününü yönlendirmek imkânını kaybetmiştir. Tümenlerle Bölge Komutanlığı arasında haberleşme kesilmiş; bu sebeple emir ve komuta da ortadan kalkmıştır ${ }^{114}$.

Güney Bölge Komutanlığı, 15 nci Tümen'in kullanılış şeklini 3 ncü Kolordu'ya danışmadan direkt olarak 5nci Ordu Komutanlığı'yla istişare etmesi emir-komuta zincirini alt üst etmiştir. Esat Paşa'nın 5 nci Ordu Komutanlığı'na gönderdiği raporda bu taarruzla ilgili hiçbir sorumluluk kabul etmeyeceğini bildirmiştir ${ }^{115}$.

Seddülbahir'deki birliklerin yeniden örgütlenmesi ve gereken muharebe şartlarının sağlanmasına kadar bulundukları mevzileri muhafaza ve Alçıtepe güneyinde savunmalarına karar verilmiş, Güney Grup Komutanlığı doğrudan 5 nci Ordu'ya bağlanmıştır. Sonunda kolordu seviyesinde dört Grup Komutanlığı doğmuştur ${ }^{116}$.

\section{Yeni Güney Grup Komutanlığı ve Salimbey Çiftliği Karargâhı}

Bir haftada büyük kayıplara sebebiyet verdikten sonra, 4 Mayıs günü Albay von Sodenstern görevinden alınmak zorunda kalınmış ve hastalık bahanesi ile derhal İstanbul'a gönderilerek yerine 15 nci Kolordu Komutanı General Weber atanmıştır ${ }^{117}$. Aynı gün Grup Karargâhı'na gelerek görevini teslim almış ve bir gün sonra da karargâhı gelmiştir ${ }^{118}$. Grup Komutanlığın muharebe idare yeri Küçükmehmet Bey Tepesi'ndedir ve karargâhı da bu tepenin hemen gerisinde kurulmuştur ${ }^{119}$.

Karargâhı Salimbey Çiftliğinde bulunan Güney Grubu, batıan doğuya doğru olmak üzere, 11 nci, 7 nci ve 2 nci Tümenleriyle savunma amaçlı tertiplenmiştir. 6 ncı ve 12 nci Tümenleri de, Alçıtepe kuzey bat bölgesindedir ${ }^{120}$. 9 ncu Tümen karargâhı, Kirte kuzeyindeki 150 Rakımlı Tepe'de kurulmuştur. Tümen muharebe idare yeri, Hilalsırt güneyindeki tepededir ${ }^{121}$.

112 ATASE Arşivi, 4/8747, Kls. 3474, Dos. H-4, F. 1-17, 1-22, 1-24.

113 ATASE Arşivi, 5/2453, Kls. 3964, Dos. H-16, F. 1-11, 1-19, 1-22, 1-24.

114 ATASE Arşivi, 6/8903, Kls. 4836, Dos. H-12, F. 1-1, 1-5, 1-6.

115 ATASE Arşivi, 6/8903, Kls. 4836, Dos. H-12, F. 1-5, 1-6;ATASE Arşivi, 5/2453, Kls. 3964, Dos. H-17, F. 1-14.

116 ATASE Arşivi, 4/8747, Kls. 3474, Dos. H-5, F. 2-4, 2-11;ATASE Arşivi, 4/8747, Kls. 3474, Dos. H-7, F. 3-29.

117 ATASE Arşivi, 4/8747, Kls. 3474, Dos. H-8, Fih. 5-55; ATASE Arşivi, 4/8747, Kls. 3474, Dos. H-9, Fih. 6; Esat Paşa'nın elinde, 4 Mayıs 1915 günü, Weber Paşa'nın Güney Grubu Komutanı olduktan sonra, tüm cephenin komutanlığından sadece Kuzey Grubu Komutanlığı kalmıştır; EPÇA, s. 556.

118 ATASE Arşivi, ATASE Arşivi, 6/8903,Dos. H-16; Fih. 1-67.

119 Karargâhının şubelerini kurmuş olan Weber, çoğu personeli henüz Anadolu yakasında bulunuyor-du

120 ATASE Arşivi, 6/10170, Kls. 4761, Dos. H-6, Fih. 1-12, 1-13, 1-15, 1-16, 1-17.

121 ATASE Arşivi, 6/8903, Kls. 4836, Dos. H-14,Fih. 1-20, 1-28. 


\section{Güney Grubuyla Iletişimsizlik}

Başkomutan Vekili, Güney Grubundan sağlıklı bilgi alamadığını birazda ihtar niteliğindeki telgrafina cevaben, Liman von Sanders, 10 Haziran'da Enver Paşa'nın şahsına, durumu izah etmeye çalışan bir mektup göndermiştir ${ }^{122}$. Sonunda 5 nci Ordu Kurmay Başkanlığı, 19 Haziran 1915'te sert ifadeli yazıyla, kesin ve doğru bilgi verilmesini istemek zorunda kalmıştir ${ }^{123}$ :

“Güney Grubu, 15.000 tüfek zayiatı olduğunu bildiriyor. Buna sebep olarak da, ilk taarruzların başarısızlıkla ve çekilmekle son bulduğu, bu nedenle de çokça kayıplara mal olduğu gösterilmektedir. Bu neden, ne orduyu ne de Genel Karargâhı tatmin eder. Güney grubu gibi savunmalar ve taarruzlar yapan kuzey grubunun silah zayiat, 2.000'i aşmıyor. Gösterilen toplam zayiatın ve hangi birliklerce ne zaman ve ne kadar verildiğinin müspet dayanaklarıyla bildirilmesini önemle rica ederim."

\section{Kolordu Komutanlıkları ve Biri Türk Diğeri Alman Komutan Atama}

Güney Grubuna 5 nci Ordu Komutanı kendi eliyle ve okunduktan sonra geri gönderilmesi kaydıyla Almanca yazılmış 7 Haziran tarihli bir emir göndermiştir ${ }^{124}$.

Madde 5. Bu günlerde özel nedenlerle bazı düzenlemeler yapılacaktır. Bu düzenlemeler kolordu komutanlarıyla karargâh ve teşkilatına atanacaklar hakkındadır. Bunun gereği olarak, Komutanı Alman olan kolordulara bir Türk Kurmay Başkanı ve aksine kurmay başkanı Alman olan kolordulara da bir Türk Kolordu Komutanı atanacaktır."

\section{Güney Grubunda Yeni Düzenleme}

Güney Grubu Komutanı'nın sorumluluğu altında bulunan bölgede, beş tümen bir alay ve ayrıca 3 ncü, 5 nci özellikle 11 nci Tümenin çeşitli sınıflarından birçok küçük kıtalar bulunmaktadır. Bu duruma bir çekidüzen vermek için Weber Paşa, Tenger Deresi'nde Salimbey Çiftliği'nden ${ }^{125} 9$ Haziran 1915'te tümen komutanlıklarına emir göndermiş; savunma hattını üç tümen bölgesine bölmüştür ${ }^{126}$.

\section{Kirte Muharebeleri ve Birliklerin Karargâhları}

ikinci Kirte muharebeleri sırasında, kısmen tahkimatını tamamlamış olan Türkler, ağırlık merkezi oluşturmak yerine, tüm cepheye saldıran Müttefikleri durdurmuştur. Hala Mayıs ayında, gerekli derin tahkimat ve tahkimat malzemesi bulunmamaktadır. Aynı zamanda topçu cephanesinde sıkıntısı çekilmektedir. Ağır topçu desteği zayıftır, var olanların da cephane çok azdır. Piyade tüfeği eksiği de çok ciddi boyuttadır. Mesela 2 nci Tümen 5 nci Alay'da2.000 askere sadece 700 tüfek vardır; askerlere, yaralı veya şehit arkadaşlarının tüfeklerini almaları emredilmiştir ${ }^{127}$.

Üçüncü Kirte muharebelerinde, Müttefiklerin merkezde gerçekleştirdikleri ilerlemeyi devam ettirememeleri, Türklerin bu noktadan yarılmasını engellemiştir.

122 ATASE Arşivi, 4/8747, Kls. 3474, Dos. H-9, Fih. 6-19, 6-36; Büyük oranda Albay von Soderstern'dan kaynaklı olan ve büyük kayıplar konusunda cevap verilmekte zorlanılan gündem sebebiyledir.

123 ATASE Arşivi, 4/8749, Kls. 3474, Dos. H-10, Fih. 1-33.

124 ATASE Arşivi, 4/8747, Kls. 3474, Dos H-9, Fih. 6-7,6-8, 6-13, 6-19, 6-24, 6-34, 6-36.

125 ATASE Arşivi, 6/8903, Kls. 4836, Dos. H-14,Fih. 1-20, 1-28.

126 ATASE Arşivi, 6/3171, Kls. 4857, Dos. H-8, Fih. 1-15.

127 ATASE Arşivi, 4/8747, KIs. 3474, Dos. H-5, F. 2-2, 2-12, 2-13. 
Bu durum, İngiliz ihtiyatının yanlış bir tercihle kanatlarda kullanmaları kadar, Türk savunmasının da merkezi zamanında güçlendirebilmesinin de bir sonucudur ${ }^{128} \cdot 19$ Mayıs'taki Arıburnu'nda büyük zayiata uğramış 2 nci Tümen, Üçüncü Kirte ve Kerevizdere muharebelerinde olağanüstü bir performans sergilemiştir. Aynı tümen birlikleri, 15 gün sonra, yine Kerevizdere'de, ateş hattında bırakılmış ve burada yok olma noktasına gelmiştir ${ }^{129}$. Sol kanat Komutanı karargâhı, Büyük Kirte Deresi'ndedir. 9 ncu Tümen muharebe idare yeri, Kirte kuzeyindeki 150 Rakımlı tepede kurulmuştur. 12 nci Tümen muharebe idare yeri, Hilalsırt güneyindeki tepededir. 7 nci Tümen, Güney Grubu Ihtiyat olarak Alibey çiftliği kuzeyindeki vadidedir ${ }^{130}$.

\section{Zığındere Muharebeleri}

Zığındere muharebelerinde bazı Türk birliklerinin Müttefikler'in bombardımanı ve saldırısı karşısında çözülmesi, düşmanın üstün ateş gücünün yanı sıra, Türk savunmasının henüz yeterince derinliğine organize olamaması sonucudur. Ileri hatlara gerekenden çok kuvvet tahsis edilmesi ${ }^{131}$, tek bir bombayla bile çok sayıda askerin zayi olmasına yol açmış; tahkimat malzemesinin kıtlığı, bu kayıpları daha da yükseltmiştir. Makineli tüfeklerle tahkim edilmiş, donanmanın yakın mesafe desteğine sahip bir düşmana karşı; yeterli topçu desteği yokken karşı hücuma kalkmak ${ }^{132}, 14.000$ zayiata yol açmıştir ${ }^{133} .28$ Haziran'da başlayan Zığındere muharebeleri 5 Temmuz'da kadar devam etmiştir ${ }^{134}$.

\section{5 nci Ordu ile Müstahkem Mevki Komutanlığının Iş̧birliği}

Enver Paşa, 3 Temmuz 1915 günü, 5 nci Orduyla Müstahkem Mevkiin işbirliği yapmalarını öngören emirde ${ }^{135}$ : Başkomutan Vekilinin bu işbirliği emri, Müstahkem Mevki 5 nci Ordu Komutanının emrine vermemekle beraber, muharebeler süresince 5 nci Ordu'nun sevk ve idaresine büyük bir rahatlık ve güvence vermiştir.

\section{2 nci Ordu Komutanı Vehip Paşa, Güney Grup Komutanı}

Verilen ağır zayiatlar sebebiyle Güney Grubu Komutanı Ferik Weber Paşa'nın görevinden alınması kesinleşmiştir. Yerine getirilecek olan Vehip Paşa, 1 Temmuz 1915 günü, yanında Kurmay Başkanı Albay Nihat, İstanbul Merkez Komutanı Yarbay Cevat ve yaverleri ile Kuzey Gruba Karargâhına-ağabeyinin yanına ${ }^{136}$ - gelmiş ve yeni görevi için durumu yakından inceleme firsat bulmuştur. Geceyi Esat Paşa'nın karargâhının ikinci kademesinin bulunduğu Bigalı'nın kuzeyindeki Çamlıbel karargâhında geçiren Vehip Paşa, İstanbul’a geri dönmüştür ${ }^{137}$.

128 ATESE Arşivi, 5/9812, Kls. 4350, Dos. H-2 Fih. 14; ATESE Arşivi, 6/8903, Kls. 4836, Dos. H-14,Fih. 1-20, 1-28; ATESE Arşivi, 6/8903, Kls. 4836, Dos. H-17, Fih. 1-4;ATESE Arşivi, 4/8747, Kls. 3474, Dos. H-8, Fih.

5-55; F. CharlesRoux, Çanakkale Seferi, Çev: Nihat ve Asım, Askeri Baনs., İstanbul 1921, s.91.

129 ATESE Arşivi, 6/8903, Kls. 4836, Dos. H-17, Fih. 1-4, 1-13.

130 ATESE Arşivi, 6/8903, Kls. 4836, Dos. H-16, Fih. 1-65, 1-66, 1-67, 1-68, 1-69, 1-70;

131 ATASE Arşivi, 6/3171, Kls. 4857, Dos. H-12, Fih. 1-12, 1-15; ATASE Arşivi, 6/2514, Kls. 4831, Dos. H-14, Fih. 1-65; 2 nci Kolordu Komutanı Faik Paşa, 29 Haziran'da, sağ kanat komutanlığına getirilmiştir. Liman Paşa, Faik Paşa'yı, 2 Temmuz'da başarısız bahanesiyle görevinden almıştır. Faik Paşa, geçici ola־rak Asya Grubu Komutanlığı'na atanmıştır. ATASE Arşivi, 4/8747, Kls. 3474, Dos. H-12, Fih. 8-33.

1323 Temmuz'da, bu kez bölgeye yeni gelen 1 nci Kolordu Komutanı Mehmet Ali Paşa, Türk sağ kanat komutanlığına getirilmiş fakat yine bir sonuç elde edilememiştir.

133 ATASE Arşivi,6/3171, Kls. 4857 Dos. H-12, Fih. 1-8.

134 ATASE Arşivi,4/8747, Kls. 3474 Dos. H-12, Fih. 8-2; ATASE Arşivi,6/8056, Kls. 4775, Dos. H-4, Fih. 1-18, 1-22.

135 ATASE Arşivi, 4/8749, Kls. 3474, Dos. H-11, Fih. 7-11, 7-57.

136 Ana-baba bir öz kardeş olmalarına rağmen, Ağabey Esat, Bülkat; Vehip ise Kaçi soyadını almışlardır. 137 ATASE Arşivi,6/282, Kls. 4763, Dos. H-7, Fih. 1-99. 
Vehip Paşa, doğrudan Başkomutanlık Vekâletine bağlı olarak Güney Grup Komutanlığı görevini alabileceğini açıklamıştı ${ }^{138}$. Başkomutan Vekilinin 4 Temmuz 1915 günlü emri, Yarımada'nın savunmasını 5 nci ve 2 nci Ordular arasında paylaştırıldığından dolayı, 5 nci Ordu Komutanı Liman von Sanders'i çok üzmüştür.

\section{Liman Paşa ve Avusturya Ateşemiliteri Güney Grubu Karargâhında}

1 nci Kolordu Komutanlığı taarruz hazırlıklarını sürdürürken, 5 nci Ordu Komutanı 4 Temmuz 1915 günü Güney Grubunu ziyarete geleceğini ve geceyi de orada geçireceğini bildirmiştir. Beraberinde Avusturya Ateşemiliteri General Pomiankovski ve Kurmay Başkanı Yarbay Kâzım (İnanç) olduğu halde Güney Grubu karargâhına gelmişler ve 5 Temmuz 1915 gününü de burada geçirmişlerdir ${ }^{139}$.

\section{Vehip Paşa ve Salimbey Çiftliği Karargâhı}

Enver Paşa yeni tayin kararıyla 5 nci Ordu'nun daha çok kuvvetlenmesi sağlanmış olmaktadır.6 Temmuz 1915 günlü Başkomutanlık Vekâletinin emriyle Vehip Paşa'nın komutasındaki 2 nci Ordu, 8 nci ve 10 ncu Tümenli 14 ncü Kolordu'yla; 13 ncü ve 14 ncü Tümenli 5 nci Kolordu'dan oluşmuştur ${ }^{140}$.

8 Temmuz 1915'te Kuzey Grubu karargâhına gelen Vehip Paşa, burada bulunan 5 nci Ordu Komutanı Liman von Sanders'le de görüşmüştür. Ertesi gün 5 nci Ordu karargâhına uğrayıp, maiyetiyle birlikte Salimbey Çiftliği karargâhına ulaştğında ilk yazılı emrini yayınlamıştır ${ }^{141}$.

Güney grubunun 10 Temmuz $1915^{\prime}$ teki yerleşmesi ${ }^{142}: 1$ nci Tümen muharebe idare yeri, Yassıtepe batısında; 11 nci Tümen muharebe idare yeri, Ocaktaşı Tepesinde; 7 nci Tümen muharebe idare yeri, Kanlıdere başlangıcında; 4 ncü Tümen muharebe idare yeri, Alibey Çiftliğindedir. 6 nci Tümen, Soğanlıdere güney sırtlarında; 5 nci Tümen, Kumdere başlangıcında ve Kirte yolu civarında intiyattadır.

Vehip Paşa, Seddülbahir cephesinde yaptı̆̆ bölge ayırımında 1 nci ve 11 nci Tümenlerle 5 nci ve 9 ncu Tümenlerden bazı kuvvetlerin bulunduğu sağ kanadın komutanlığına Mirliva Trommer Paşa'yı görevlendirmiştir. Sol kanattaki (7 nci, 4 ncü Tümenlerle ihtiyattaki 6 nci Tümen) kuvvetleri de kendi komutası altına almıştır.

5 nci Kolordu Komutanı Mirliva Fevzi Paşa (Çakmak), Kurmay Başkanı ve karargâhının bir bölümüyle 12 Temmuz 1915 günü gelebilmiş ve 4 ncü, 6 nci ve 7 nci Tümenlerin bulunduğu sol kanat bölge komutanlığı görevine başlamıştır.

\section{2-13 Temmuz Muharebeleri}

12-13 Temmuz muharebelerinde de Türk kayıpları çok ağırdır. Savaş dışı kalan 10.000 'e yakın birlikten sadece yaklaşık $1.000^{\prime}$ i şehit olduğu, 4.000'inin yaralandığı bilinmektedir. Geriye kalan 4.568 kişiden sadece 600'ü esir düşmüştür ve geriye kalan 3.968 er ve subaydan daha sonra hiç haber alınamamıştır ${ }^{143}$.

138 ATASE Arşivi, 4/8747, Kls. 3474, Dos. H-31, Fih. 1-4.

139 ATASE Arşivi,4/8747, Kls. 3474, Dos. H-12, Fih. 8-2.

140 ATASE Arşivi, 4/8749, Kls. 3474, Dos. H-12, Fih. 8-25.

141 ATASE Arşivi, 6/282, Kls. 4763, Dos. H-7, Fih. 1-99, 1-104, 1-114

142 ATASE Arşivi, 4/8747, Kls. 3474, Dos. H-31, Fih. 1-4.

143 ATASE Arşivi,5/9962, Kls. 3974, Dos. H-1, Fih. 1-105. 


\section{Ikinci Kerevizdere Muharebeleri}

Başkomutanlık, 5 nci Ordu'ya her yeni bir kıta verilmesinden sonra zaman geçirilmeden taarruza geçilmesi isteğinin tekrarlanmasını alışkanlık haline getirmiştir. Bu kez Enver Paşa, 15/16 Temmuz 1915 günü 5 nci Ordu'ya gönderdiği telgrafta, bundan böyle, acele etmeden ve tedbirli hareket edilmesini öğütlemektedir ${ }^{144}$.

Enver Faşa, 17 Temmuz 1915'te 5 nci Ordu Komutanına gönderdiği telgrafta, düşmanın Saros'tan bir çıkarma yapabileceği uyarısında bulunmuştur ${ }^{145}$ :

“Ingilizlerin Saros'a çıkarma için hazırlık yaptıklarına ait söylentiler sürüyor. Yarımada'nın güneyinde zor durumda kaldıklarından bu kez Saros'a çıkarak ordunun karayla bağlantısını kesinlikle daha kesin bir harekete kalkışmalarını umuyorum."

Ertesi gün, 18 Temmuz 1915'te Başkomutan Vekili Enver Paşa, bir telgraf emri daha göndermiştir ${ }^{146}$ : "Düşman Saros'a çıkarma yapmaya kalkışırsa, büyük ihtimalle Bolayır hattının gerisine yani batısına yapacağını sanıyorum."

Başkomutanlıkla İkinci Kerevizdere muharebeleri öncesinde başlayan çalışma ve yazışmalar, bir türlü tatmin edici sonuca ulaşamamış; üstelik mermi harcamalarında tutumlu olunması tavsiyeleri alınmıştır.

\section{Başkomutan Vekili Enver Paşa Cephede}

Başkomutan Vekili Enver Paşa, 28 Temmuz 1915'te Çanakkale cephesine gelmiş ve cepheyi kendi gözüyle görmüştür ${ }^{147}$.

\section{Ağustos 1915'te Birliklerin Durumu}

Saros Grubu: 16 nci Kolordu Komutanı Kurmay Albay Feyzi Bey'dir ${ }^{148}$. Grup karargâhı Gelibolu'da olup, görev alanı Enez'den despot Limanına kadar bölgeyi kapsamaktadı1 ${ }^{149}$. 7 nci Süvari Alay ile Kuruçeşme'de, 11 nci Süvari Alayıyla Yerlisu kuzeyinde, 13 ncü Süvari Alayı ve Bağımsız Süvari Tugayıyla Kısırkaya'da bulunmaktadır. Piyade taburu Turfan'da, Keşan Jandarma Taburu da Sazlıdere'dedir. 6 ncı Tümen'in karargâhı Ortaköy'de, 17 nci Piyade Alayıyla Kocaçeşme ile Kavaksuyu arasında $16 \mathrm{ncı}$ Piyade Alayı ile Kavaksuyu Cemilbey Çeşmesi arasındadır. Karargâhı Bolayır İskelesinde bulunan 12 nci Tümen, 36 ncı Piyade Alayıyla Cemilbey Çeşmesi-Bolayır arasındaki bölgede; 35 nci Piyade Alayıyla Bolsazlık-Kanak limanı arasındadır. Karargâhı Molla Mustafa Çiftliği'nde bulunan 7 nci Tümen, 21 nci ve 22 nci Piyade Alaylarıyla Kanak ve Despot limanları arasındaki bölgede; 20 nci Piyade Alayı Kavaklı kuzeyinde ihtiyattir ${ }^{150}$.

Saros grubu, İngiliz veya Fransızların Berzah bölgesine çıkarma yapmasını daha olası görmüş; birlikleri gereğinde harekâta müdahale için kısmen toplu bulundurmuş, süvari tugayıyla da diğer kesimlere vakit geçirmeden yerleşmiştir.

Tayfur Bölgesi: 4 ncü Süvari Alayı, Lej Burnu’yla Ece Limanı arasındaki bölgede, kuvvetlerinin çoğunu Tayfur'da bulundurmaktadır.

144 ATASE Arşivi, 4/8749, Kls. 3474, Dos. H-32, Fih. 20-14.

145 ATASE Arşivi,4/8749, Kls. 3474, Dos. H-13, Fih. 9-45.

146 ATASE Arşivi,4/8749, Kls. 3474, Dos. H-13, Fih. 9-50.

147 Genelkurmay, Çanakkale Cephesi 3 nci Kitap, s. 263.

148 ATASE Arşivi,4/8747, Kls. 3474, Dos. H-13, Fih. 9-24.

149 ATASE Arşivi, 4/8747, Kls 3474, Dos. H-14. Fih. 10-5.

150 ATASE Arşivi,4/8747, Kls. 3474, Dos. H-13, Fih. 9-8; ATASE Arşivi, 4/8747, Kls 3474, Dos. H-14. Fih. $10-7$. 
Anafarta Bölgesi: Koyun Limanıyla Azmakdere arasındaki bölge, Anafarta Bölge Komutanlığının sorumluluğuna verilmiştir. Bölge komutanlığı ve Karargâhı, Çamlıtekke'de bulunuyordu. Kıyı gözetlemesine göre tertiplenmiş, bir bölüğüyle Ece Limanını, bir bölüğüyle de Suvla Limanı bölgesini tutmuş; kalan birliklerle de, Büyük Anafarta bölgesinde toplanmıştır.

Kuzey Grubu: 19 ncu, 16 ncı ve 9 ncu Tümenlerle Arıburnu kesiminde savunmaya göre tertiplenmiş, 5 nci Tümeni Kocadere kuzeyinde ihtiyata alınmıştı.5 nci Tümen karargâhı ve bağlı birlikleriyle, Matikdere'dedir. Topçu birlikleri, Conkbayırı güney sırtları-Kemalyeri sırtları gerisinde mevzilenmiştir ${ }^{151}$.

19 ncu Tümen karargâhı, Düztepe güneyindedir. Bu tümen, 14 ncü Piyade Alayı ara hattyyla Kemalyeri ile Kırmızısırt arasındaki bölgede 72 nci, 18 nci, 27 nci ve 57 nci Alaylarıyla mevzide olmak üzere savunma düzenini almıştır ${ }^{152}$.

Karargâhıyla Kemalyeri bir buçuk kilometre güneyinde bulunan 16 nci Tümen,

19 ncu Tümen ara hattiyla Hacı Andon Çiftliği güneyindeki Azmakdere arasındaki bölgededir. 77 nci Alay, Hacı Andon Çiftliği kuzeyindedir. Karargâhı Kayaltepe'de bulunan 9 ncu Tümen, Azmak Deresiyle Kum Deresi arasındaki bölgede bulunmaktadır ${ }^{153}$.

Güney Grubu: Güney grubunun karargâhı, Salimbey çiftliğindeydi. 4 ncü ve 8 nci Tümenlerden oluşan 2 nci Kolordu, 4 Ağustos 1915'te kurulmuştur. Kolordu karargâhı, Sarafim çiftliğinin güneyindeki 172 Rakımlı Tepe'dedir ${ }^{154}$.

14 ncü Kolordu Komutanı Tuğgeneral Trommer Paşa'dır. 14 ncü Kolordu cephenin sağında/batısındadır. Karargâhıyla Çobanevi mevziinde bulunan Yarbay Cafer Tayyar komutasındaki 1 nci Tümen; Karargâhını, Yassıtepe doğusunda Kirte yolu civarında kurmuş olan 10 ncu Tümen, Komutanı Yarbay Selahattin yönetimindedir ${ }^{155}$.

Albay Fevzi Paşa komutasındaki 5 nci Kolordu'nun, 13 ncü Tümeni sağda, 14 ncü Tümen solda Kirte Deresi doğu kolundadır. Karargâhıyla Alçıtepe kuzeyinde Soğanlıdere mansabında bulunan13 ncü Tümen Albay Hovik, karargâhıyla Hilalsırtı doğusunda bulunan 14 ncü Tümen Yarbay Kâzım yönetimindedir ${ }^{156}$.

4 Ağustos günü itibariyle 2 nci Kolordu, Tuğgeneral Faik Faşa komutasındadır. Karargâhı, Sarafim Çiftliğinin iki kilometre güneyinde 172 Rakımlı Tepe batısındadır. Grup ihtiyatı olarak 4 ncü Tümeni, Melekhanım çiftliği ve doğusu bölgesinde; 8 nci Tümeni de, 150 rakımlı Yassıtepe kuzeyinde bulunmaktadır ${ }^{157}$. Alınan bu tedbirler sonunda Güney Grubu, Ağustos 1915başından beri, güvenilir bir duruma girmiş; beklenen yeni bir taarruza karşı, güvenceyle savunacak düzeye ulaşmıştr. Güney grubu, İngilizlerin Anafartalar'a yapmak istediği çıkarmayı gizlemek ve dikkatleri başka yöne çekmek amacıyla 6-13 Ağustos 1915 günleri arasında cephesine art arda yönelttiği taarruzları başarıyla geri püskürtmüştür ${ }^{158}$.

151 ATASE Arşivi, 1/1666, Kls. 4618, Dos. 43, F. 71; ATASE Arşivi, 6/9665, Kls. 4996, Dos. H-3, F. 1-1.

152 ATASE Arşivi, 6/8903, Kls. 4836, Dos. H-10, F. 1-68

153 ATASE Arşivi, 6/7832, Kls. 4883, Dos. H-7, Fih. 1-17.

154 ATASE Arşivi, 4/8749, Kls. 3474, Dos. H-14, Fih. 10-29, 41; ATASE Arşivi, 5/9962, Kls 3974, Dos. H-1, Fih. 1-114.

155 ATASE Arşivi, 5/2743, Kls. 3955, Dos. H-14, Fih. 1-21, 22; ATASE Arşivi,5/9187, Kls. 4360, Dos. H-5, Fih.48,4-9, 4-10

156 ATASE Arşivi, 5/9962, Kls. 3973, Dos. H-2, Fih. 7-9.

157 Genelkurmay, Çanakkale Cephesi 3 nci Kitap, s. 278.

158 ATASE Arşivi,5/9962,Kls 3974, Dos. H-11Fih. 1-114. 
Güney Grubu Komutanı Tuğgeneral Vehip Paşa, Kerevizdere muharebelerinden sonra bölgede hüküm sürmeye başlayan durgunluktan yararlanarak, köklü düzenlemelere girişmiş ve geri hizmetleri düzene koymaya başlamıştır ${ }^{159}$ :

Weber Paşa döneminde, tüm geri hizmetler, kol ve katarların yönetimi, geri bölgenin disiplinin sağlanması görevi Binbaşı Schroeder'e verilmişti ${ }^{160}$. Karargâhı Kilye'de bulunan ve başına Kurmay Albay Sadık Sabri'nin getirildiği bir 'Geri Bölge Komutanlığı' kurulmuş, bir kurmay subay, bir doktor, bir jandarma subayı ile yarım süvari bölüğü verilmiştir ${ }^{161}$.

Asya Grubu ${ }^{162}$ : Asya Grubu Komutanlığı, 2 nci, 3 ncü, 11 nci Tümenlerle 1 nci

Kolordu bağı birliklerinden oluşmaktadır. Asya grubunun 3 Ağustos 1915'ten itibaren kesinleşen savunma düzeninin alınmasına, İngiliz ve Fransızların nerelere çıkarma yapabileceğinin kıymetlendirilmesi ve gereğinde başka bölgelere kuvvet kaydırma düşüncesi etkili olmuştur.

Asya yakasına geçirilen 11 nci Tümen, karargâhıyla Pınarbaşı'nda: 127 nci Alay, Sarıçalı doğusunda; 126 nci Alay, Pınarbaşı doğusunda toplu olarak bulunuyordu. Bu tümenin 33 ncü Piyade Alayı, 30/31 Temmuz gecesi, Kilye'ye geçirilmek üzere Çanakkale'ye hareket etmiştir.

\section{ARIBURNU (KANLISIRT VE CONKBAYIRI) MUHAREBELERI}

\section{Kanlısırt Muharebeleri ${ }^{163}$}

Kuzey Grubunun 6 Ağustos 1915 günü, Arıburnu cephesindeki savunma düzeni:

Sazlıdere ile Azmakdere (Karatepe güneyinde) arasındaki cephenin sağında (kuzeyde) 19 ncu Tümen, solunda (güneyde) 16 ncı Tümen olmak üzere mevzide bulunmaktadır. 19 ncu Tümen muharebe idare yeri, Düztepe'nin 500 metre güneyinde Topsırt’nda; 16 ncı Tümenin muharebe idare yeri de Adanabayırı'ndadır. 5 nci Tümen, Kurucadere Köyü kuzeyi ile güneybatısında Grup ihtiyatındadır ${ }^{164}$.

Sazlıdere kuzeyinde, Binbaşı Willmer komutasındaki Anafarta müfrezesi 32 nci Alayın 1 nci Taburuyla 14 ncü Alaydan oluşmaktadır. Azmakdere güneyinde, 9 ncu Tümen, Albay Kannengiesser komutasındadır ${ }^{165}$.

Kanlısırt'ın düşman tarafindan ele geçirilmesinde, özellikle Türk siperlerinin üzerinin top ateşine karşı kalın kalaslarla kapatılması önemli bir handikap teşkil etmiş; Türk askerleri bunların altındaki siper şebekelerinde mahsur kalarak çok ağır zayiat vermiştir. 27 nci Alay Komutanı Şefik Bey'in müdahalesiyle, aynı sistemin 19 ncu Tümen cephesindeki Türk siperlerinde uygulanmaması, muhtemel ve daha büyük bir felaketi engellemiştir $^{166}$.

159 ATASE Arşivi, 5/9817, Kls. 4350, Dos. H-6, Fih. 1-36.

160 Genelkurmay, Çanakkale Cephesi 3 nci Kitap, s. 279.

161 Aynı yer.

162 ATASE Arşivi, 5/10136, Kls. 4539, Dos, H-6, Fih. 1-106.

163 ATASE Arşivi, 4/8747, Kls. 3474, Dos. H-14, Fih. 1-17; ATASE Arşivi, 6/7832, Kls. 4883, Dos. H-7, Fih. 1-21; Kanlısırt muharebelerinde el bombalarının büyük rol oynamış olmasıdır. Kesin olmamakla birlikte 6 Ağustos'tan 10 Ağustos gününe kadar geçen süre içindeki Türk zayiat, 7.164 kişidir. Bunun 1.520'si şehit, 4.750'si yaralı ve 760'ı kayıptır. 134 kişi kadar da, esir vermiştir.

164 ATASE Arşivi, 5/9904 Kls. 4532, Dos. 26, Fih. 1, 16.

165 ATASE Arşivi, 6/7832, Kls. 4883, Dos. H-7, Fih. 1-17.

166 ATASE Arşivi, 6/7832, Kls. 4883, Dos. H-8 Fih. 1-2, 1-5, 1-6, 1-7. 


\section{Conkbayırı Muharebeleri (Ingiliz Kuşatma Saldırısı) $)^{167}$}

Sazlıdere'yle Ağıldere arasından 6 Ağustos günü saat 22.00'de taarruz eden ve mevcudu $\mathbf{2 0 . 0 0 0 ~ k i s ̧ i y i ~ b u l a n ~ I ̇ n g i l i z l e r , ~ C o n k b a y ı r ı ~ v e ~ K o c a c ̧ i m e n t e p e ' y e ~ t a a r r u z ~ e t m i s ̧ t i r . ~ B a s ̧ l a n g ı c ̧ - ~}$ ta, süratle ilerlemiş ve bu tepelerin doruk çizisine 25-30metreye kadar yanaşabilmiştir ${ }^{168}$. Tutulan Conkbayırı civarı ve etekleri, başta intiyat kuvvetlerinin parça parça ve arazinin durumu dikkate alınmadan bölgeye yığılması, sorumlu komutanların vurularak savaş dışı kalması, emir - komuta düzenini felce uğratmıştır. Conkbayırı'na lüzumundan fazla kuvvet yığılmasına rağmen, toplanan kuvvetler belli bir hedefe yönlendirilememesi yüzünden bir türlü başarı elde edilememiştir. Anafartalar Grubu Komutanlığına atanan Albay Mustafa Kemal, yorgun ve ağır zayiat vermiş olan Türk birliklerine yeni bir ruh vermiş; 10 Ağustos 1915 günü saat 04.30'da topçu hazırlık ateşi yapılmadan, sadece süngüsünü kullandırarak yeniden taarruza geçirmiştir ${ }^{169}$. Sonunda Anafartalar Grubu Komutanı Mustafa Kemal ve ona bağlı birlik komutanlarıyla, askerlerin gösterdikleri büyük direnç ve fedakâr hücumlar sayesinde kazanılmıştır ${ }^{170}$.

6 Ağustos'ta başlayıp10 Ağustos 1915 günü akşamı sona eren kanlı ${ }^{171}$ muharebelerde İngiliz birlikleri geri atımış; Kanlısırt-Kocaçimentepe-Conkbayırı hatt, emniyet altına alınmış; İngilizler, taarruz gücünü yitirmişlerdir ${ }^{172}$.

\section{Yeni Amfibi Harekât: Suvla ve Anafartalar (6/7 Ağustos 1915)}

Anafartalar sahilleri, kuvvetli bir şekilde savunulmamakta ve Türk topçusunun menzili dışında kalmaktadır. Ayrıca Suvla limanı bir ileri üs oluşturacak konumdadır. Sahile çıkacak olan birlikler hâkim tepeler hattından, Tekketepe - Küçük Anafarta ve Büyük Anafarta üzerinden Kocaçimentepe'ye ulaşarak, hem Boğazıa inmek hem de Arıburnu'ndaki Türk kuvvetlerini çevirmek gibi iki manevra imkânı bulacaktı ${ }^{173}$.

Arıburnu ve Conkbayırı muharebeleri, aslında Müttefikler'in Anafartalar'a ve Suvla Limanı'na yaptıkları yeni çıkarmayla başlayan büyük harekâtın bir parçasıdır ${ }^{174}$.

6 Ağustos 1915günü saat 22.00'de başlayan çıkarma harekât, 20.000'den fazla İngiliz askerini kapsamaktadır. Bu bölgeyi savunan Yarbay Willmer komutasındaki Türk kuvvetlerinin sayısı 3.000 kadardır ve 31 nci ve 32 nci Alaylardan birer taburla, Gelibolu ve

167 Cemil Conk, Çanakkale, Conkbayırı Savaşları, Ankara Genelkur־may Basımevi, 1959, s.23.

168 Zayıf kuvvetlerle tutu-lan ve kısmen gözetlemeyle yetinilen bu tepeler hattına yöneltilen kuşatmasında İngiliz ihtiyat birlikleri, süratle ve zamanın־da savaşlara müdahale ettirilerek başarının geliştirilmesinde kullanılma-mışlardır. Ayrıca arazi keşfinin yaptırılmaması ve izlenecek yolların işa-ret ettirilmemesi, koordineli bir taarruzun yapılamamasına neden olmuş; kısım kısım taarruza kalkan İngiliz birlikleri, Türk topçu ve makineli tü-fek ateşlerinin etkisi ve karşı taarruzları karşısında başarı sağlayama-mıştır.

169 ATASE Arşivi, 6/9040, Kls. 4798, Dos,H-4, Fih. I-137; ATASE Arşivi, 6/9040, Kls 4798, Dos, H-2, Fih. 1-100, 1-102, 1-103, 1-104, 1-105, 1-107; Aspinall-Oglander, C. II,s.175; Conk, Kroki:1.

170 ATASE Arşivi, 6/9565, Kls. 4936, Dos. H-35, Fih. 1-2, 1-3, 14; ATASE Arşivi, 6/9040, Kls. 4798, Dos. H-4, Fih. 1-136, 1-137; ATASE Arşivi, 6/9040, Kls 479S, Dos, H-2, Fih. 1-100, 1-103, 1-104; ATASE Arşivi, 6/8565 Kls. Dos. H-34, Fih. 1-4; ATASE Arşivi, 4/8747, Kls. 3474, Dos. H-15, Fih. 11-18; ATASE Arşivi, 6/2219 Kls. 4853, Dos. H-9, Fih. 1-190,1-195; ATASE Arşivi, 4/8747, Kls. 3474, Dos. H-15, Fih. 11-5; Kadri Perk, Çanakkale Savaşının Tarihi 2 ve 3 ncü Kısımlar, Askeri Basımevi, İs-tanbul 1940, s. 120, 124; Aspinall-Oglander, C II, s. 201, 203, 204, 208; Çalışlar, s.139.

171 Kanlısırt-Conkbayırı muharebelerinde Türkler 20.000; Ingilizler 25.000 zayiat vermişlerdir; Perk, s.124.

172 ATASE Arşivi, 6/9565, Kls. 4936, Dos. H-35, Fih. 1-2,1-3.

173 Robert Rhodes James, Gelibolu Harekât, Çev: Haluk V. Saltıkgil, Belge Yayınları, İstanbul 1972, s. 350; Aspinall-Oglander, C. II, s. 233, 239, 241, 248, 269.

174 Aspinall-Oglander, C. II, s. 271, 288, 289, 305312. 
Bursa Jandarma Taburları, bir süvari bölüğü ve bir istihkâm bölüğünden oluşmaktadır. Anafartalar olarak adlandırılan bölgede iki dağ ve bir sahra bataryasından oluşan 12 namluluk bir topçu gücü vardır ${ }^{175}$.

İngilizler zayiat vermeden ve bir dirençle karşılaşmadan karaya çıkmışlardır. Küçük Kemikli Burnu'nun ucundaki Lalebaba tepeyi ele geçiren İngilizler, kıyı şeridini güvene almışlar, fakat ilerlememişlerdir. Suvla Limanı́nın hemen kuzeyindeki Softatepe'deki Bursa Jandarma Taburuna bağlı iki bölük asker de, İngilizler'i, sabahın ilk ışıklarına kadar ateş altında tutmuş ve ciddi zayiat verdirmiştir. Sadece kıyı postaları da, İngilizlere ciddi bir vakit kaybettirmişlerdir ${ }^{176}$. Saat 08.00 'de Softatepe İngilizlerin eline geçince, buradaki Türk birlikleri, Kireçtepe ve Mestantepe yönlerine çekildiler ${ }^{177}$.

İngiliz harekâtı bu saatlerden sonra, esas olarak ileri bir harekât olmaktan çıkmış ve kıyı kesiminde çakılı kalmıştı. Büyük organizasyon ve koordinasyon problemleri yaşayan, aynı zamanda ciddi su sıkıntısı çeken İngilizler; sadece sınırlı sayıda birliklerle, Kireçtepe ve Mestan Tepe yönüne doğru ilk önemli taarruzu 17.30'a doğru başlatabilmişlerdir. Sayıları 22.000'i bulan İngilizler, Mestan Tepe'yi ve Kireçtepe başındaki Karakol Dağı'nı 1.700 kişi zayiatla ele geçirebilmişlerdir ${ }^{178}$.

Az zayiat veren Türk birlikleri 8 Ağustos gününü İsmailoğlu Tepe ve Kireçtepe üzerinde tahkimat yaparak ve başlayacak İngiliz saldırısını bekleyerek geçirmişlerdir. Sayılan 27.000'e yaklaşan İngilizler ise, sahil civarında beklemekte; 3.000 askerlik Türk birlikleri karşısında "altın firsatlar" kaçırmaktadır. Hava karardıktan sonra İngiliz öncü birlikleri ilerlemiş, Yusufçuk Tepe ve Tekke Tepe eteklerine kadar gelmiştir ${ }^{179}$.

Liman Paşa'nın emriyle Bolayır'dan yola çıkan 7 nci ve 12 nci Tümen'e bağlı alaylar, 25 ile 40 km arasında değişen bir mesafeyi yürüyerek kat edecekler ve Anafartalar savunmasını destekleyeceklerdir. Bu birlikler ancak sabah ve öğlen saatlerinde yola çıkabilmiş ve zorlu bir yürüyüşten sonra, emredilen karşı hücum için, 8 Ağustos günü 10.30 civarında hazır olup, ancak pozisyon alabilmişlerdir ${ }^{180}$.

Saros Grubu Komutanı iken, yeni amfibi harekât üzerine tesis edilen Anafartalar Grubu Komutanlığı'na getirilen Albay Feyzi Bey, tümen komutanlarının da görüşleri doğrultusunda, askerin yorgun olması ve birliklerin tümünün muharebe alanına ulaşmaması nedeniyle, akşamüzeri için planlanan saldırıdan vazgeçmiştir. Bunun üzerine Liman von Sanders, Feyzi Bey'i görevden almış ve bir telefon emriyle Albay Mustafa Kemal'i Anafartalar Grubu Komutanlığı'na atamıştır ${ }^{181}$. Mustafa Kemal 8/9 Ağustos gecesi Çamlıtekke'ye gelerek komutayı devralmış ${ }^{182}$ ve 5 nci Ordu Komutanlığı tarafindan emredilen karşı hücumun, gecikmeyle de olsa, 9 Ağustos sabahı aynen daha önceden tasarlandığı gibi gerçekleştirileceğini belirtmiştir ${ }^{183}$.

175 ATASE Arşivi, 6/8565, Kls. 4936, Dos. H-85, Fih. 1-3.

176 ATASE Arşivi, 6/9040, Kls. 4798, Dos. H-4, Fih. 1-136.

177 ATASE Arşivi, 8/2514, Kls. 4831, Dos. H-16 Fih. 1-7;Kadri Perk, s. 118.

178 ATASE Arşivi, 6/9565, Kls. 4936, Dos. H-35, Fih. 1-5.

179 ATASE Arşivi, 5/8810, Kls. 4575, Dos. H-2, Fih. 1-1.

180 ATASE Arşivi, 4/8747, Kls. 3474, Dos. H-15, Fih, 11-3, 11-4,

181 ATASE Arşivi, 4/8747, Kls. 3474, Dos. H-15, Fih, 11-5, 11-18.

182 ATASE Arşivi,4/8749, Kls.3474, Dos. H-15, Fih. 11-18; ATASE Arşivi, 8/2514, Kls. 4831, Dos. H-16 Fih. 1-7; ATASE Arşivi, 1/217, Dos. 36, Fih. 125, 131.

183 ATASE Arşivi, 6/3267, Kls. 4863, Dos. H-12, Fih. 1-15. 


\section{Anafartalar Grubu Komutanı Mustafa Kemal ve Çamlıtekke Karargâhı}

Anafartalar Grubu Komutanlığı'na atanan Albay Mustafa Kemal8/9 Ağustos gecesi Çamlıtekke'ye gelerek komutayı devralmıştı ${ }^{184}$. Kurmay Başkanı İzzeddin ${ }^{185}$, “Kumandayı Kemal Bey'e teklif ettiler o da şart dermeyan etti. Orada bulunan Tümenlerin kumandasını istedi. Başta pek razı olmadılar. Sonra Ordu Komutanı muvafakat etti. Anafartalar Grubu komutanlığını tevcih ettiler. 19 ncu Tümen Komutan vekâletine de Şefik Bey tayin oldu. Gece yarısı Kemal Bey Çamlıtekke'ye gitti ve emir ve kumandayı deruhte etti." ... "15 Ağustos 1915akşamı derhal Anafarta Grubu karargâhına hareketim emir olundu. Takriben iki buçuk saat yol yürüdüm. Bir Tümenden bir de Şimal Grubu'ndan yol bilir iki süvari önden, ben de seyisim ile arkadan Çataldere, Uzundere, Kocaçimen, Anafarta Çamlıtekke'ye saat 23.00'te geldim. Komutan uyumuştu. Biraz Erkânı Harbiye Reisi Hayri (Tarhan) Bey'le oturduk. Sonra bana da bir çadır gösterdiler."...."Dünkü muharebede grup karargâhının hareketi hakkında, "harp ceridesi186"ne geçmek üzere bir rapor yazdım. Çamlıtekke'de iyi vakit geçiriliyor (17 Ağustos 1915)."

Ayan ve Mebusan üyelerinden bir kısmının Çanakkale cephesini ziyareti sırasında Falih Rıfkı Atay ${ }^{187}$, "Nihayet Anafartalar'a vardık. Henüz albay rütbesinde bulunan Mustafa Kemal, Grup komutanı idi. Karargâh şimdi gözümün önündedir; adeta köşk gibi bir şeydi. Kendimizi bir an İsviçre dağlarında sandık. Her şey öyle yerli yerinde idi ki, top sesleri işitmesek kendimizi gezide zannedecektik. ... Karargâh kesilmiş odunlardan sanki muharebe için değil de, huzur içinde denizi seyretmek gibi... Kameriye biçiminde bir zeminlikti. Mustafa Kemal, ölüm karşısında bile hayat yaratiyordu. Mustafa Kemal, aza heyetine karargâhı gezdirdikten sonra, bizi hazırladığı yemek sofrasına davet etti. Liste şöyle idi: Dügün çorbası, patatesli et, bamya, fasulye, börek, pilav, tatıı."

\section{Birinci Anafartalar Muharebesi ${ }^{188}$}

9 Ağustos'ta, 7 nci Tümen Büyük Anafartalar Köyü arkasından Damakçılık bayırına; 12 nci Tümen Küçük Anafartalar Köyü arkasından İsmailoğlu Tepe, Yusufçuk Tepe ve Sülecik üzerinden Mestan Tepe'ye hücum edecektir. Bursa Jandarma Taburu ve 31 nci Alay İsmailoğlu Tepe'den taarruzlara katılacak ve irtibatı sağlayacaktır.

İki tarafın da taarruza karar verdiği 9 Ağustos günü, Türkler daha erken davranmış ve ilerleyen İngilizleri geri atmış; ağır kayıplar verdirmiş olmasına rağmen İsmailoğlu Tepe ve Yusufçuk Tepe'yi tutmaya devam etmişlerdir. Kireçtepe üzerinde saldırıya geçen Ingilizler fazla ilerleyememiştir.

7 nci Tümen, gün ağarırken daha güneyden taarruza kalkmış, fakat İngiliz siperlerine 300 metre kala başlayan şiddetli makineli tüfek ateşleri yüzünden, daha fazla ilerleyememiştir.

184 Aynı belge.

185 Çalışlar, s.139,141.

186 “Ceride sözcüğü gazete, zabıtname ve tutanak anlamına gelmektedir. Harp ceridesi ise bir askeri birliğin savaş esnasında tuttuğu ve her türlü gelişmenin kaydedildiği günlük mahiyetini de taşıyan tutanaklardır. Harp cerideleri resmi belge niteliğinde olup savaş, ordu, coğrafya, iklim, teşkilat, yazışmalar gibi pek çok konuda önemli bilgiler ihtiva etmektedir." Mehmet Mercan, "Tarih Kaynağı Olarak Harp Cerideleri", Tarih Dergisi, İstanbul 2009, S.46, s.273.

187 Falih Rıfkı Atay, Babamız Atatürk, Doğan Kardeş Yayınları, İstanbul 1955, s.28.

188 ATASE Arşivi, 5/8810, Kls. 4558, Dos. H-6, Fih.3-1; ATASE Arşivi, 5/8810, Kls. 4574, Dos. H-4, Fih. 1-16; ATASE Arşivi, 1/217, Dos. 36, Fih. 125, 131; Perk, s.118. 
Daha sonra saldırıya devam edilmesine, hatta 4 ncü Tümen'in de sağ kanadıyla bu saldırıyı desteklemesine rağmen, ilerleme mümkün olmamış ve ağır kayıplar veren Türkler, Kayacıkağılı doğusuna çekilmiştir. İlk gün sona erdiğinde, Anafartalar ovasındaki hâkim tepeler Türklerin elindedir ve İngilizler hedeflerinden çok uzaktadır. 13.000 civarında Türk askeri, 2.000 'in üzerinde zayiat vermiş; ama sayıları 20.000 'i aşan İngilizleri durdurmuştur.

10 Ağustos günü, İngilizler Küçük Anafartalar yönüne doğru, 12 nc Tümen cephesine taarruza kalkmışlardır. Birkaç saat süren bu saldırıdan sonuç alamayıp, öğleye doğru yoğun bombardımandan sonra, bu kez Yusufçuk Tepe'ye hücum etmeye başlamıştır. İki alay, hem mevcudu, hem bundan sonra akşama kadar iki kez daha tekrarlanan saldırıları püskürtmeyi başarmıştır.

11 Ağustos günü, İngilizler 10.000 kişilik yeni bir kuvveti daha karaya çıkarmışlar ve Tekke Tepe'ye doğru sürmüşlerdir. Bununla birlikte, yeterli hazırlık olmadığını düşünen İngiliz kurmayları, taarruzu 13 Ağustos'a ertelemişlerdir. Bu harekâtın başarısızlıkla sonuçlanması üzerine, İngilizler 13 Ağustos için planladıkları ana harekâttan vazgeçtiler.

7-13 Ağustos tarihleri arasındaki Anafartalar muharebelerinde Türk kayıpları 4.000'in üzerinde, aynı sürede, İngiliz kayıpları ise 8.000 kişi civarındadır.

Anafartalar harekâtından sonuç alamayan İngilizler, 14 Ağustos'tan itibaren, Kireçtepe'yi hedef alan bir saldırıya karar vermişler; hedef olarak da cepheden mağlup edemedikleri 12 nci Tümen kuvvetlerini arkadan çevirmek ve daha sonra Tekke Tepesyi ele geçirmektir. Donanma atehinin himayesinde öğleden sonra, Sivri Tepe üzerinden hücuma kalkıp, Aslan Tepe ve Projektörtepe'yi ele geçirmiştir. İki gün süren Kireçtepe muharebelerinde, Türk birliklerinin zayiat 1.700, İngilizlerin 2.000 'di.

Bu muharebelerden sonra, 21 Ağustos tarihine kadar Anafartalar cephesinde büyük çapta bir operasyon olmamıştı. Yeniden düzenlenen Türk savunması kuzeyden başlayarak, Kireçtepe'de yeniden kurulan Yarbay Willmer komutasındaki 5 nci Tümen, İsmailoğlu Tepe'de 12 nci Tümen, Kayacık Ağılı ve Bomba Tepe civarında 7 nci Tümen, Abdurrahman Bayırı civarında 4 ncü Tümen ve Kocaçimentepe-Conkbayırı-261 Rakımlı Tepe hattında ise 8 nci Tümen şeklindedir. 9 ncu Tümen iki alayı Turşunköy'de, 6 ncı Tümen'in iki alayı da Sivli Köy'de intiyattadır.

\section{Bolayır Bölgesi ve 1 nci Ordu Komutanlığı ${ }^{189}$}

Bu arada, 25 Nisan'dan beri düşman çıkarmaları konusunda soru işaretleri barındıran Bolayır bölgesi 1nci Ordu emrine verilmiş ve Gelibolu Yarımadası'nı savunan 5 nci Ordu'nun sorumluluk alanı dışına çıkmıştır. 5 nci Ordu Komutanı, daha rahat bir nefes almak olanağını bulmuştur. Anafartalar bölgesine ilişkin olarak, topçu kuvvetleri de yeniden düzenlenmiştir.

1 nci Ordu Komutanlığı da, 24 ncü Tümenin Saros Grubu mevzilerini teslim alma emrini aldığını ve 6 nci Kolordu karargâhının da 18 Ağustos 1915 günü Gelibolu'ya geleceğini bildiriyor.Ağustos 1915 sonunda tümüyle Saros Bölgesi Komutanlığı ulaşmış ve bu bölgenin savunmasını yüklenmiş bulunan 1 nci Ordu'ya bağlı 6 nci ve 17 nci Kolordularının (6 nci Kolorduyla 26 ncı Tümenin 28 Ağustos 1915'te 5 nci Ordu emrine Sivli'ye hareketinden sonra) durumu şöyle olmuştur: 1 nci Ordu emrine girmiş bulunan Bağımsız Süvari

189 ATASE Arşivi,4/8749, Kls. 3474, Dos. H-16, Fih. 2-23, 2-25. 
Tugayı ve Keşan Jandarma Taburu, eskiden olduğu gibi, Enez'den Kocaçeşme'ye kadar uzanan kıyının gözetleme ve savunmasında görevlendirilmiştir.

Kurmay Başkan Izzeddin ${ }^{190}$,"(20 Ağustos 1915) Karargâhta uzun uzadıya meşgul oldum. Muharebede şiddet yok. Vaziyet iyi. Golç Paşa geldi. Komutan 4 ncü Tümen cephesine gitmişti. Haber verildi geldi. Harbiye Dairesi Reisi Şükrü Bey de Golç Paşa'nın maiyetindeydi. Biraz karargâhta oturduktan sonra yemek yediler. Sonra otomobil ile Komutanla birlikte gözetleme mevkiine çıkmışlar. Faik Paşa da oradaydı."

\section{Çamlıtekke Karargâhı'nda Bayan Muhabir}

Kurmay Başkan Izzeddin"191"(22 Ağustos 1915)Akşam, Polonya gazeteleri muhabirlerinden bir madam geldi ve bizde yemek yedi. Gece arabayla iade edildi. Avrupa kadını bir maksat ve gaye için harp meydanını geziyor."... "Akşam karargâha Polonyalı muhabir kadın yine geldi ve birlikte yedik."

\section{ikinci Anafartalar Muharebesi}

Değişik tip ve çapta 97 toptan oluşan ciddi bir kuvvet, hâkim tepeler silsilesi ve gerisinde konuşlandırılmıştır ${ }^{192}$.

85 namluluk kara topçu desteğine sahip Müttefikler, Seddülbahir'den gelen destekle, 30.000 kişilik bir kuvvete erişmiş ve yeniden saldırı planı hazırlamıştı ${ }^{193}$.

Anafartalar Grubu Komutanı, yeni kuvvet kaydırmalarından, İngilizlerin bu cephede yeni saldırı hazırlandıklarını anlamış; ihtiyatları cepheye yaklaştırmıştı ${ }^{194}$.

Saldırı, 21 Ağustos günü 14.30'da, özellikle İsmailoğlu Tepe ve Yusufçuk Tepe üzerinde yoğunlaşan bir topçu ateşinden sonra başlamış, Yusufçuk Tepe ve güneyine saldıran düşman kolu, buradaki ön siperleri ele geçirdiyse de, etkili yan ateşleri karşısında çekilmek zorunda kalmıştır. Saat 18.00 'de saldırı tekrarlanmış, yine çok az bir ilerleme sağlayabilmişlerdir. Kayacıkağılı yönünde saldıran birlikler, 7 nci Tümen cephesindeki siperleri ele geçirip tahkimata başlamıştir ${ }^{195}$.

Gece yapılan muharebede bazı ön siperler el değiştirdiyse de, 22 Ağustos gününe gelindiğinde, sadece Yusufçuk Tepe'nin denize bakan yamaçları ile Azmak Dere ve Kayacık Ağılı civarında küçük bir arazi parçası elde edebilmişlerdir ${ }^{196}$.

Bu bir günlük çarpışma, Müttefikler'in tüm Çanakkale muharebeleri boyunca bir seferde uğradıkları en ağır zayiat ortaya çıkardı. İngilizler yaklaşık 8.000 asker kaybettiler. Türklerin kayıpları ise 2.500 askeri geçiyordu ${ }^{197}$.

\section{Başkomutan Vekili Enver Paşa Cephede}

Kurmay Başkanı İzeddin"198, “(24 Ağustos 1915)Enver Paşa'nın teşrifleri münasebetiyle pek erken kalktık. Enver Paşa, evvela karargâha uğramadan Kocaçimen'e gittiler.

190 Çalışlar, s. 142.

191 A.g.e., s. 143

192 ATASE Arşivi, 1/217, Dos. H-44, Fih. 1-21, 127.

193 ATASE Arşivi, 4/8747, Kls. 3474, Dos. H-17, Fih, 3-3.

194 ATASE Arşivi, 4/8747, Kls. 3474, Dos.11, Fih, 4-19.

195 ATASE Arşivi, 5/8810, Kls. 4574, Dos. H-5, Fih. 1-5

196 ATASE Arşivi, 4/8747, Kls. 3474, Dos. H-16, Fih. 2-22, 2-23.

197 ATASE Arşivi, 4/8747, Kls. 3474, Dos. H-16, Fih. 2-25, 2-31.

198 Çalışlar, s.143. 
Sonra karargâha uğradılar. Bronzart Paşa ve Liman Paşa beraberdiler. Karargâhta Almanya Ateşemiliteri Lossowda vardı. Bir saat kadar oturduktan ve grup vaziyeti hakkında Komutanla görüştükten sonra otomobillerle 5 nci Tümen cephesine, Kireçtepe'ye gittiler."

\section{Kayacıkağılı (Bombatepe) Muharebeleri (27 Ağustos 1915)}

İngilizler, sağdaki Anzak birlikleriyle cephe hattında bağlant kurmak için, Bomba Tepe'yi ele geçirmeye çalışmak olmuştur. 27 Ağustos günü, güneşi arkalarına alarak bu yönde yoğunlaşan ağır bombardımandan sonra taarruza geçen Müttefikler; Bomba Tepe'nin güneybatı sırtlarını ele geçirmişlerdir. Bu küçük tepe üzerindeki mücadele, sabah saatlerine kadar sürmüş ve iki tarafta da ağır kayıplara yol açmıştır (İngilizler 1.100, Türk birlikleri 679 asker).

Bomba Tepe muharebeleri ile Arıburnu ve Anafartalar bölgesindeki çarpışmalar fiilen sona ermiş oluyordu. Anafartalar Muharebeleri de Conkbayırı muharebeleri gibi, hazırlıksız ve plansız yakalanan Türk savunmasının, hem düşmanın gereken operasyonel kabiliyet ve kararlılığı gösterememesi yüzünden, hem de Anafartalar Grubu Komutanı Mustafa Kemal ve ona bağlı birlik komutanlarıyla, askerlerin gösterdikleri büyük direnç ve fedakâr hücumlar sayesinde kazanılmıştır.

\section{Başkomutan Vekili Enver Paşa Cephede}

Başkomutan Vekili Enver Paşa, Harekât Şubesi Müdürü Yarbay İsmet Bey ile 24 Eylül 1915'te Gelibolu'ya gelerek önce 6 ncı Kolordu'ya uğramış; sonra, doğruca Güney Grubuna giderek incelemelerde bulunmuş ve karargâh subaylarından bilgi almıştr. 25 Eylül 1915'te Asya yakasına geçerek orada da durumu yerinde incelemiş ve 26 Eylül 1915 günü 5 nci Ordu karargâhına dönmüştür. Aynı gün Ordu karargâhında da incelemeler yaptıktan sonra, Yarımada'dan ayrılmıştır. Bu temasların amacı, Çanakkale Cephesinin sükûnete kavuştuğu bu günlerde, karmakarışık durumda olan kıtaların biran önce asıl kuruluşlarına kavuşturmaktır.

Kurmay Başkanı İzzeddin"199 "(26 Eylül 1915)Enver Paşa sabahleyin Şimal Grubu'na gitmiş ve bizim cephede Conkbayırı́nı gezmiş. Sonra orduya gitmiştir Bize gelmedi."

\section{3 ncü Kolordu Kurmay Başkanı Fahrettin (Altay) Bey Müsteşar Muavini}

Kurmay Başkanı İzeddin²00 "(24 Eylül 1915)Akşamüzeri Fahrettin veda için geldi. Istanbul'a müsteşar muavinliğine gidiyor."

\section{3 ncü Kolordu Komutanı Esat Paşa 1 nci Ordu Komutanı}

Kurmay Başkanı İzzeddin"201,"(14 Ekim 1915)Hava pek serin. Meşguliyet çok. Öğleden sonra Liman Paşa karargâha geldi. Esat Paşa 1 nci Ordu Komutanlığına tayin edilmiş. Kendisini tebrik ettim. Golç Paşa da 6 nci Ordu (Irak) Komutanlığına tayin olmuş."

\section{Suriye Edebi Heyeti Cephede}

Kurmay Başkanı Izzeddin'202"(21 Ekim 1915)Hava iyi. Suriye heyeti edebiyesini istikbal için Kumköyü'ne kadar otomobil ile gittim. Heyet reisi Esat Essefit Efendi'ye yanı hoşamedi ettim. Heyete büyük bir resmikabul yapıldı Kumköy’de bir süvari bölüğü ile

199 A.g.e., s. 150.

200 Aynı yer.

201 A.g.e., s. 153.

202 A.g.e., s. 154. 
ve Kumköy ile karargâh arasında bütün 26. Tümen ile istikbal ettik. Askerlere mevizeler okudular. Karargâhta Komutan Bey'e (Atatürk) karşı Arapça methiyeler okudular. Heyet azasından her birisi birer beliğ hatipti. 59. Alay yanındaki tepeye çıktılar. Meydanı harbi seyrettiler. Sonra yemek yedik. Yemekten sonra posta posta Tümen cephelerine gittiler."

\section{Enver Paşa Cephede}

Kurmay Başkanı İzeddin²03,"(31 Ekim 1915)Enver Paşa, İzet Paşa, Feldmann, Seryaver Kazım (Orbay) Bey karargâhımıza geldiler. Sonra hayvanlarla Ismailoğlu Tepesi'ne gidildi."

\section{Ayan ve Mebusan Heyeti Cephede}

Kurmay Başkanı Izzeddin"204,"(3 Kasım 1915) Ayan ve Mebusan heyeti geldiler. Saruhan mebusu Sabri Bey de vardı. Komutanla 59 tarassuduna gittiler. Muharebeyi gördüler. Öğle taamım birlikte yaptık. Benim bulunduğum sofrada Sabri (Saruhan) Sudi (Lâzistan), Kâzım (Kal'ai-sultaniye) Veli (Aydın) beyler ile Urfa ve Trablusşam mebusları vardı. Muş Mebusu ilyas Efendi'ye bir tüfek hediye ettim. Meydanı harpten sakladığım tüfek ona kısmetmiş. ilyas Efendi askere hitaben bir mevize okudu".

\section{Mustafa Kemal Bey'in Himayesi}

Kurmay Başkanı İzzeddin"205, “(4 Kasım 1915)Karargâhta meşgul olduk. 11 nci Tümen'de Topçu Binbaşısı Hamdi Bey ile Grup Topçu Komutanı Von Berg arasında bir münazaa oldu. Hamdi, Von Berg'in emirlerini reddetti. Mesele biraz kritik. Fakat Hamdi'yi divan-ı harbe vermekten kurtardık. Mustafa Kemal Bey himaye etti. Mesele sükûnet buldu."

\section{9 ncu Tümen ve Anafartalar Grup Komutanlığı Kurmay Başkanı Kurmay Binbaşı Izzeddin'in Kemalyeri, Düztepe ve Çamlıtekke Karargâh Bilgileri}

Kurmay Başkanı İzzeddin, karargâhta yaptı̆̆ hizmetlerden kesitler sunar:

"Kuzey Gruba defni emvat işleri ve düşman ve bizim mevziimiz hakkında iki rapor yazıp gönderdim (25 Mayıs)"... "Çamlıtekke'de şube işlemleriyle meşgul oldum. Şubenin taksimi görevini yaptım. Dünkü muharebede grup karargâhının hareketi hakkında, "harp ceridesi'ne geçmek üzere bir rapor yazdım (17 Ağustos)"... "Terfi defterleri ikmal edildi (8 Eylül)"..."19 ncu Tümen Komutanı Şefik Bey'e mektup gönderdim, Arıburnu'nda ilk muharebe günlerine ait raporumu istedim (11 Ekim)"..."Vaziyeti tetkik ederek haritaya işaret ettim (3 Ağustos)"... "Son muharebelerde üstün hizmet edenlerin taltif defterleriyle uğraştik (14 Ağustos)"..."Muharebe, Karargâhtan telefonla idare edildi(14 Ağustos)..... "Grup karargâhına bizim Cevdet de memur oldu, geldi. Sabahtan gece yarısına kadar aralıksız meşguliyet vardır (14 Ağustos)."... "Terfi defterleri ikmal edildi (8 Eylül)."

19 ncu Tümen Kemalyeri, Düztepe ve Anafartalar Grup Komutanlığı Çamlı tekke karargâhını ziyaret eden yerli ve yabancı muhabir ve gazeteciler:

"Karargâhımıza ecnebi Alman ve Macar gazetecileri gelmiştir (8 Mayıs)"... "Karargâha Ajans Müdürü Hüseyin Tosun Bey ve Müdafaa-i Milliye gazetesinden Ali Ekrem Bey geldiler (1 Temmuz)"... "Öğleden Tasvir-i Efkâr muhabirlerinden Ferit Bey misafir geldi.

203 A.g.e., s. 156.

204 Aynı yer.

205 Aynı yer. 
Onunla Cesaret siperlerini gezdim (10 Temmuz)"... “Akşam, Polonya gazeteleri muhabirlerinden bir madam geldi. Gece arabayla iade edildi. Avrupa kadını bir maksat ve gaye için harp meydanını geziyor (21 Ağustos). Akşam karargâha Polonyalı muhabir kadın yine geldi (24 Ağustos) 206"... "Akşam karargâha bir ihtiyar Alman muhabiri geldi. 2 nci Kolordu Karargâhı'na götürdük(2 Eylül)"... "Sinema almak üzere Ordu'dan Necati Bey isminde birisi geldi. Grup heyetinin birkaç vaziyette resmi alındı (8 Eylül)"... "Abdurrahmanbayırı'ndan vaziyeti gözlemledim. Yanımda Tanin Muhabiri Ekrem Bey ve Sinemacı Necati Bey vardı. Kayacıkağıı'na bir top ateşi açtırdık. Sineması alındı (10 Eylül)"

19 ncu Tümen Kemalyeri, Düztepe ve Anafartalar Grup Komutanlığı Çamlı tekke karargâhını ziyaret eden diğer Ziyaretçiler ${ }^{207}$ :

Karargâhı ziyarete gelen hiç eksik olmamıştır: Edirne Valisi Hacı Adil Bey, Gelibolu Mutasarrıf, Maydos Kaymakamı(16 Mayıs),Talat Bey, Hacı Adil Bey, İsmail Canpolat Bey, Ömer, Abdülkadir, Nazım Bey'ler (5 Haziran), Eceabat Kaymakamı (25 Haziran), Mustafa Kemal Bey'in eniştesi Lütfü Efendi (5 Temmuz), Gelibolu Mutasarrıfi Süreyya ve Eceabat Kaymakamı Rahmi Bey'ler (17 Temmuz),Eceabat Kaymakamı Rahmi Bey (30 Ağustos), Bursa Sultanisi Edebiyat Muallimi Baha Bey (31 Ağustos), İstanbul'dan Beyazıt dersiamlarından Hüseyin Hilmi Efendi vaaz ve nasihat için (5 Ey/ül),Sobranya azasından Gümülcine Mebusu İsmail Hakkı Bey (21 Eylül). Biga'dan Derbentzade İzzeddin Efendi (4 Ekim) geldiler.

Heyet reisi Esat es Sefit Efendi'ye karşıladım. Heyete büyük bir resmikabul yapıldı. Kumköy'de bir süvari bölüğü ile ve Kumköy ile karargâh arasında bütün 26 ncı Tümen ile karşıladık(21 Ekim). ${ }^{208 " \prime}$

"Ayan ve Mebusan heyeti geldiler. Saruhan mebusu Sabri Bey de vardı. Komutanla 59 tarassuduna gittiler. Harp cephesini gördüler. Öğle yemeğini birlikte yaptı. Benim bulunduğum sofrada Sabri (Saruhan), Sudi (Lâzistan mebusu), Kâzım (Kala-i Sultaniye mebusu), Veli (Aydın mebusu) Beyler ile Urfa ve Trabulusşam mebusları vardı. ilyas Efendi askere hitaben bir mevize okudu (3 Kasım)."

\section{SONUÇ}

Bu araştırmada Müttefiklerin bölgeden çekilmesine kadar Çanakkale Boğazı, civar sahillerde ve karada icra edilecek olan savunma faaliyetlerinin yürütülmesi için kurulacak olan karargâhlarla ilgili bilgi verilmeye çalışıımıştı. Bu amaca ulaşmak nitel araştırma yöntemlerinden doküman analizi tekniği kullanılmıştır. Mevcut dokümanlar askeri ve devlet arşivlerinden, askeri eserlerden ve anılardan taranarak elde edilmiştir. Barış döneminde var olan karargâhlara ilave olarak, birliklerin Çanakkale'ye yanaştırılmasından itibaren yeni karargâhların kurulması ihtiyacı doğmuştur. Özellikle 25 Nisan 1915 - 9 Ocak 1916 gününe kadar 259 gün süren Çanakkale kara muharebeleri, dar bir alanda çok büyük çarpışmaların yaşandığı ve karşııklı büyük kayıpların verildiği cephede ve Boğazın her iki tarafinda çok fazla karargâh kurma intiyacı doğmuştur. Avrupa'da savaş başlar başlamaz 2 Ağustos 1914'te Harbiye Nezareti'nin üst katında,'Karargâh-ı Umumi ve Başkumandanlık Vekâleti'nin kurularak Harbiye Nazırı Enver Paşa'nın göreve başlamıştır.

206 BOA, DH. EUM. VRK, 25/41, (3, 17, 18, 19 Ağustos 1915)

207 Bu başıık altında ağırlıklı olarak sadece cepheye dışarıdan gelen ziyaretçilere yer verilmiştir.

208 Kassam Umumi Müşaviri Uryanizâde Ali Vahid, Çanakkal’a Cephesi’nde Duyup Düşündüklerim, Darü'lHilafeti'I-İlmiyye-Necm-i İstikbal Matbaası, İstanbul 1332-1334, s.3-6; Sebilü'r-Reşad, C.14 (29 Teşrin-i evvel 1331, İstanbul 1331, s.102-103;Abdülkadir Karahan, "Bir Arap İlmi Kurulu Gözü İle Atatürk", Hürriyet Gazetesi, 10-11 Kasım, İstanbul1981, s. 5. 
Savaşla birlikte kara birliklerinin bölgeye yaklaştrılıncaya kadar Çanakkale Müstahkem Mevki Komutanlı̆̆ı, bölgenin yegâne savunma birimidir. Komutanı Cevat Paşa olup karargâhı Çimenlik Kalesi'dir. Savunmanın devamını oluşturan 3 ncü Kolordu, karargâhıyla Tekirdağ'dadır. Komutanı Esat Paşa'dır. Çanakkale cephesi için özel 5 nci Ordu Komutanlığı kuruldu ve başına Alman Mareşal Liman von Sanders getirildi. Alman Mareşal, karargâhını Gelibolu'da kurdu. 5 nci Ordu Menzil Müfettişliği karargâhını Akbaş Limanı'nda, Asya yakasına gönderilen Alman General Weber Paşa, Kalvert Çiftliği'ndeki hazır karargâha yerleşti. Müstahkem Mevki Komutanlığı zaten Çimenlik kalesinde ve 3 ncü Kolordu komutanı Esat Paşa da karargâhıyla Gelibolu'da idi.

Kara muharebelerinin başladığı 25 Nisan 1915 gününden itibaren, bazen Müttefiklerin muharebe stratejilerine paralel olarak, bazen de mecburen yeni karargâhların kurulması veya yer değiştirmesi olağan hale gelmiştir. Kara muharebeleri öncesi, Müstahkem Mevki karargâhı, erken tarihte,25 Şubat 1915 bombardımanı günü, karargâhını daha güvenli yer olan üç kilometre güneybatısındaki Hacıpaşa Çiftliği'ne taşımak zorunda kalmıştır. Kara muharebeleriyle birlikte 5 nci Ordu Komutanlığı üç, 3 ncü Kolordu Komutanlığı iki, 19 ncu Tümen Komutanlığı dört defa karargâh değiştirmek zorunda kalmıştir. Bu tür mecburi değişimlerle ilgili pek çok uygulama mevcuttur.

Savaş devamettiği için kara, deniz ve hava bombardıman ve saldırılarından etkilenmeyecek, korunaklı bir yerin seçilmiş olmasına gayret gösterilmiştir. Karargâh mahallinin seçimine paralel olarak, muharebe alanlarında hâkim ve korunaklı alanların seçilmesine de dikkat edilmiştir. Bu seçim esnasında ordugâhlar ve muharebe idare yerleriyle irtibatın sağlanmasına da özel hassasiyet gösterilmiştir.

Telefon, telgraf hizmetlerinin ifası için muhabere görevlerinin her an hazır olması sağlanmıştır. Harita, kroki gibi üzerinde çalışılacak materyallerle, kırtasiye malzemelerinin her an hazır bulundurulması sağlanmıştır. Dahası yazışmalara cevap hazırlanması, istihbarati bilgileri değerlendirmesi, üst birimlerle irtibat kurulması, stratejik toplantilar yapılması, 'harp ceridesi' hazırlanması, emirler hazırlama, ziyaretçileri ağırlama ve uğurlama, mutat günlük işleri kesintisiz yapma gibi pek çok hizmet yapılmıştır. Karargâh subayı dâhil karargâh görevlileri ve görevleri tespit ve tayinine her zaman özen gösterilmiştir. Bu yapının ve içinde yaşayanların güvenliği için bir birlik bulundurulması sağlanmıştır.

Herkesin gözü kulağı Çanakkale'den gelecek İngiliz zaferi haberine kilitlenmiş; bazı cephelerde savaşlar bekleme aşamasına bile gelmiştir: Çünkü Çanakkale cephesinden gelecek bir İngiliz zafer haberi, tüm muharebeleri sonlandırabilecek haber demektir. Bu haber aynı zamanda İstanbul'un elde edilmesi, Rusya ile birleşme ve Almanya'yı baharın sonunda yenme müjdesi demektir. Aradan aylar geçtikçe, sansürün de etkisi ile cepheden gelen haberler özellikle asker gönderen milletleri tatmin etmekten uzak idi. Çünkü sansürlenmiş haberler kimseyi tatmin etmiyordu. Bu yüzden pek çok ülke sansürsüz bilgiye ulaşabilmek için, cepheye muhabirler göndermiştir. Muharebe yaklaşık bir yıla yakın sürdüğü için, çok sayıda gelen ziyaretçi sebebiyle cephe ve karargâhlar çok canlı ve hareketlidir: Başkomutan Vekili'nden, nazırlara, 'ayan'lara milletvekillerine, valilere, kaymakamlara, edebi heyete, Suriye edebi heyeti, subay ve komutan yakınlarına, Ege bölgesinden gelen haber, mektup ve hediye getiren 'sai' ye kadar herkesle karşılaşmak mümkündür.

Sonuç olarak karargâhlar, muharebeler esnasında çok büyük görevler ifa etmiş ve cepheyi, karşılıklı olarak İstanbul'daki Genel Karargâh'a, 5 nci Ordu'ya ve 2 nci Ordu'ya bağlayan, hemen ulaşabilecek niteliğe sahip, herkesin rahat uğrayabileceği idare ve komuta merkezleridir. 


\section{BÍBLIYOGRAFYA}

BOA, HR. MA,1118/4.

BOA, HR. MA, 1143/72, 1144/20, 1144/5 (22 Eylül 1915)

BOA, DH. EUM. VRK, 25/41, (3, 17, 18, 19 Ağustos 1915)

BOA, DH. EUM. 3. Şb. 2/48.

BOA, i, 1333, Ca. $/ 36$.

BOA, HR. SYS, 2109/11, 2110/3, 2323/1.

BOA, DH, EUM,3.Şb, 4/4.

ATASE Atatürk Arşivi, Dos. 6-35, Def. 8, F. 1-11, 1-12, 1-13, 1-15, 18, 1-25, 1-26, 1-32.

ATASE Atatürk Arşivi, Dos. 6-35, Def. 9, F. 1-2, 1-4, 1-5.

ATASE Atatürk Arşivi, Dos. 6-35, Def. 10, F. 1-6, 1-7, 1-13.

ATASE Arşivi, 1/1, Kls. 14, Dos. 69, F. 33.

ATASE Arşivi, 1/1, Kls. 64, Dos. 22, F. 1-38.

ATASE Arşivi, 1/1, Kls. 180, Dos. 774, F. 1-5, 1-6.

ATASE Arşivi, 1/217, Dos. 36, Fih. 125, 131.

ATASE Arşivi, 1/217, Dos. H-44, Fih. 1-21, 1-27.

ATASE Arşivi, 1/6, KIs. 1129, Dos. 27, F. 2.

ATASE Arşivi, 1/65, Kls. 1886, Dos. 50, F. 1-3.

ATASE Arşivi. 1/65, Kls. 1964, Dos. 305, F. 1-106-107.

ATASE Arşivi. 1/1666, Kls. 4618, Dos. 43, F. 71.

ATASE Arşivi, 4/8749, Kls. 3474, Dos. H-1, F. 1-4, 1-5.

ATASE Arşivi, 4/8749, Kls. 3474, Dos. H-2, F. 2-8, 2-17, 2-18, 2-25.

ATASE Arşivi, 4/8747, Kls. 3474, Dos. H-4, F. 1-8, 1-10.1-18,1-17, 1-22, 1-24,1-25.

ATASE Arşivi, 4/8747, Kls. 3474, Dos. H-5, F.2-2, 2-3, 2-4, 2-5, 2-11, 2-12, 2-13,2-19,2-20, 2-30, 2-35.

ATASE Arşivi, 4/8747, Kls. 3474, Dos. H-6, F.3, 3-15,3-16,3-24, 3-27, 3-30.

ATASE Arşivi, 4/8747, Kls. 3474, Dos. H-7, F. 3-29.

ATESE Arşivi, 4/8747, Kls. 3474, Dos. H-8, Fih. 5-55.

ATASE Arşivi, 4/8747, Kls. 3474, Dos. H-9, Fih. 6, 6-7,6-8, 6-13, 6-19, 6-24, 6-34, 6-36.

ATASE Arşivi, 4/8747, Kls. 3474, Dos. H-12, Fih. 8-2,8-33.

ATASE Arşivi,4/8747, Kls. 3474, Dos. H-13, Fih. 9-8, 9-24.

ATASE Arşivi,4/8747, Kls. 3474, Dos. H-14. Fih. 1-17, 10-5,10-7.

ATASE Arşivi, 4/8747, Kls. 3474, Dos. H-15, Fih, 11-3, 11-4,11-5, 11-18.

ATASE Arşivi, 4/8747, Kls. 3474, Dos. H-16, Fih. 2-22, 2-25, 2-31.

ATASE Arşivi, 4/8747, Kls. 3474, Dos. H-17, Fih, 3-3.

ATASE Arşivi, 4/8747, Kls. 3474, Dos.11, Fih, 4-19.

ATASE Arşivi, 4/8747, Kls. 3474, Dos. H-31, Fih. 1-4.

ATASE Arşivi, 4/8749, Kls. 3474, Dos. H-10, Fih. 1-33.

ATASE Arşivi, 4/8749, Kls. 3474, Dos. H-11, Fih. 7-11, 7-57.

ATASE Arşivi, 4/8749, Kls. 3474, Dos. H-12, Fih. 8-25.

ATASE Arşivi, 4/8749, Kls. 3434, Dos. H-14, Fih.. 5-38.

ATASE Arşivi,4/8749, Kls. 3474, Dos. H-14, Fih. 10-29, 41.

ATASE Arşivi,4/8749, Kls.3474, Dos. H-15, Fih. 11-18.

ATASE Arşivi,4/8749, Kls. 3474, Dos. H-16, Fih. 2-23, 2-25.

ATASE Arşivi, 4/8749, KIs. 3474, Dos. H-32, Fih. 20-14.

ATASE Arşivi, 5/2453, Kls. 3964, Dos. H-15, F. 1-21, 1-31, 1-33.

ATASE Arşivi, 5/2453, Kls. 3964, Dos. H-16, F. 1-11, 1-19, 1-22, 1-24.

ATASE Arşivi, 5/2453, Kls. 3964, Dos. H-17, F. 1-14, 1-25.

ATASE Arşivi, 5/2453,Kls.3964, Dos. H-22, F. 1-12. 
ATASE Arşivi, 5/2453, Kls. 3964, Dos. H-23, F. 1-1, 1-7, 1-11.

ATASE Arşivi, 5/2453, Kls. 3964, Dos. H-61, F. 1-27.

ATASE Arşivi, 5/2743, Kls. 3955, Dos. H-14, Fih. 1-21, 22.

ATASE Arşivi, 5/8810, Kls. 4574, Dos. H-5, Fih. 1-5.

ATASE Arşivi, 5/8810, Kls. 4575, Dos. H-2, Fih. 1-1.

ATASE Arşivi, 5/8810, Kls. 4558, Dos. H-6, Fih.3-1.

ATASE Arşivi,5/9187, Kls. 4360, Dos. H-5, Fih.4-8,4-9, 4-10

ATASE Arşivi, 5/9812, Kls. 4350, Dos. H-2 Fih. 14.

ATASE Arşivi,5/9817, Kls. 4350, Dos. H-6, Fih. 1-36.

ATASE Arşivi, 5/9904, Kls. 4532, Dos. 26, Fih. 1, 16.

ATASE Arşivi, 5/9962, Kls. 3973, Dos. H-2, Fih. 7-9.

ATASE Arşivi,5/9962, Kls. 3974, Dos. H-11, Fih. 1-105.1-114.

ATASE Arşivi, 6/1666, Kls. 4668, Dos. 72, F. 4.

ATASE Arşivi, 6/1666, Kls. 4669, Dos. H-1, F. 1-5, 1-10, 1-49, 1-74.

ATASE Arşivi, 6/1666, Kls. 4669, Dos. H-3, F. 1-78, 1-79, 1-80.1-83.

ATASE Arşivi, 6/1666, Kls. 3964, Dos. H-7, F. 1-15.

ATASE Arşivi, 6/1666, Kls. 4624, Dos. 70, F. 1.

ATASE Arşivi,6/1666, Kls. 4669, Dos. H-12, F. 1-63, 1-85.

ATASE Arşivi, 6/1666, Kls. 4669, Dos. H-13, F. 1-1, 1-6, 1-19, 1-21, 1-22, 1-23.

ATASE Arşivi,6/2514, Kls. 4831, Dos. H-I, F, 1-5.

ATASE Arşivi, 6/2514, Kls. 4831, Dos. H-14, Fih. 1-65.

ATASE Arşivi, 6/2219, Kls. 4853, Dos. H-9, Fih. 1-190,1-195.

ATASE Arşivi, 6/3171, Kls. 4857, Dos. H-8, Fih. 1-15.

ATASE Arşivi, 6/3171, Kls. 4857, Dos. H-12, Fih. 1-8, 1-12, 1-15

ATASE Arşivi, 6/7832, Kls. 4883, Dos. H-7, Fih. 1-17.

ATASE Arşivi, 6/7832, Kls. 4883, Dos. H-8 Fih. 1-2, 1-5, 1-6, 1-7.

ATASE Arşivi, 6/3267, Kls. 4863, Dos. H-12, Fih. 1-15.

ATASE Arşivi, 6/8056, Kls. 4775, Dos. H-2, F. 1-1, 1-2, 1-3, 1-5, 1-6, 1-7, 1-8, 1-9, 1-10, 1-11, 1-12, 1-13,1-15.

ATASE Arşivi, 6/8903, Kls. 4836, Dos. H-7, F. 1-53.

ATASE Arşivi, 6/8903, Kls. 4836, Dos. H-10, F. 1-14, 1-15, 1-17, 1-20, 1-68,1-71, 1-72, 1-73, 1-78, $1-79,1-80,1-81,1-82,1-83,1-84,1-85.1-86,1-89$.

ATASE Arşivi, 6/8903, Kls.4836, Dos.H-11, F. 1-18, 1-I9, 1-22, 1-23, 1-24, 1-26, 1-27, 1-28, 1-29, 1-31, 1-33.

ATASE Arşivi, 6/8903, Kls. 4836, Dos. H-12, F. 1-1, 1-5, 1-6.

ATASE Arşivi, 6/8903, Kls. 4836, Dos. H-14,Fih. 1-20, 1-28.

ATASE Arşivi, 6/8903, Kls. 4836, Dos. H-16, Fih. 1-65, 1-66, 1-67, 1-68, 1-69, 1-70.

ATASE Arşivi, 6/8903, Kls. 4836, Dos. H-17, Fih. 1-4, 1-13, 1-44, 1-45, 1-46.

ATASE Arşivi, 6/8056, Kls. 4775, Dos. H-4, Fih. 1-18, 1-22.

ATASE Arşivi, 6/8903, Kls. 4836, Dos. H-17, Fih. 1-4, 1-13.

ATASE Arşivi, 6/282, Kls. 4763, Dos. H-7, Fih. 1-99, 1-104, 1-114

ATASE Arşivi, 6/7832, Kls. 4883, Dos. H-7, Fih. 1-17, 1-21.

ATASE Arşivi, 6/8565 Kls. Dos. H-34, Fih. 1-4.

ATASE Arşivi, 6/8565, Kls. 4936, Dos. H-85, Fih. 1-2, 1-3, 1-4, 1-5.

ATASE Arşivi, 6/9040, Kls. 4798, Dos, H-2, Fih. 1-100, 1-102, 1-103, 1-104, 1-105, 1-107.

ATASE Arşivi, 6/9040, Kls. 4798, Dos. H-4, Fih. 1-136, 1-137.

ATASE Arşivi, 6/9565, Kls. 4936, Dos. H-5, F. 1-2.

ATASE Arşivi. 6/9665, Kls. 4996, Dos. H-3, F. 1-1.

ATASE Arşivi, 6/10170, Kls. 4761, Dos. H-6, Fih. 1-12, 1-13, 1-15, 1-16, 1-17. 
ATASE Arşivi, 7/9592, Dosya H-I-3.

ATASE Arşivi, 7/9746, Kls. 5337, Dos. H-I, F. 1-1, 1-2, 1-3, 1-4, 1-5.

ATASE Arşivi, 7/9746, Kls. 5338, Dos. H-3, F. 1-7.

ATASE Arşivi. 7/9746, Kls. 5337, Dos. H-4, F. 1-4, 1-10, 1-16.

ATASE Arşivi, 7/9746, Kls. 5337, Dos. H-5, F. 1-1, 1-23, 1-26, 1-27, 1-28, 1-29.

ATASE Arşivi, 7/9746, Kls. 5337, Dos. H-6, F. 1-2, 13.

ATASE Arşivi. 7/1831, Kls. 5774, Dos. H-I, F. 1-110.

ATASE Arşivi, 8/2514, Kls. 4831, Dos. H-16 Fih. 1-7.

ATASE Arşivi, 8749, Kls. 3474, Dos. H-13, Fih. 9-45, 9-50.

Türk Silahlı Kuvvetleri Tarihi, I. Dünya Harbinde Türk Harbi, C.V, 2. Kitap, Çanakkale Cephesi Harekât, Ankara, 1977.

Genelkurmay Başkanlığı, I. Dünya Harbinde Türk Harbi, C.V, 3. Kitap, Çanakkale Cephesi Harekâtı, Ankara, 1980.

Aker, Ş., Çanakkale - Arıburnu Savaşları ve 27 nci Alay, İstanbul, 1935.

Altay, F., On Yıl Savaş ve Sonrası, Eylem Yayınları, İstanbul, 2008.

Alganer, Haydar Mehmet, Çanakkale Kara Savaşları Günlüğü, Çanakkale Deniz Müze Komutanlığı Yayınları, İstanbul, 2009.

Aspinall-Oglander, C.F., Çev. Tahir Tunay, Çanakkale Gelibolu Askeri Harekâtı, C. I-II, Askeri Matbaa, İstanbul, 1939.

Atatürk'ün Bütün Eserleri, C. I (1903-1915), 3. Basım, Kaynak Yayınları, Analiz Basım Yayın Tasarım Uygulama, İstanbul, 2003.

Atay, F.R., Babamız Atatürk, Doğan Kardeş Yayınları, İstanbul, 1955.

Belen, F., Birinci Dünya Harbinde Türk Harbi 1915 Yılı Hareketleri, Kara Kuvvetleri Komutanlığı Yayınları, Genelkurmay Basımevi, Ankara, 1963.

Binbaşı Nihat, Seddülbahir Muharebât, Erkan-ı Harbiye Mektebi Yayınları, İstanbul, 1921.

Binbaşı Mahmut Sabri, Seddülbahir'in IIlk Şanlı Müdafaası, Yeni Anadolu Basımevi, Konya, 1933.

Bülkat, E., Esat Paşa'nın Çanakkale Anıları, Baha Matbaası, İstanbul, 1975.

Conk, C., Çanakkale, Conkbayırı Savaşları, Ankara Genelkurmay Basımevi, 1959.

Çalışlar, İ. ve I. Görgülü, (Yay.Haz.), İzzeddin Çalışlar'ın Defterinden On Yılık Savaşın Günlüğü, Güncel Yay., İstanbul, 2007.

Desmazes, R., Nak. BinbaşıBahaeddin, Çanakkale Seferi, Büyük Erkan-ı Harbiye Reisliği X. Şube, Askeri Matbaa, İstanbul, 1930.

Görgülü, İ., On Yıllık Harbin Kadrosu, Türk Tarih Kurumu Yayınları, Ankara, 1993.

Kemalyeri, A.M., Çanakkale Ruhu Nasıl Doğdu ve Azerbaycan Savaşı1917-1918, Baha Matbaası, İstanbul, 1972, s.18.

Kannengiesser, H., Çanakkale Cehenneminde 500 Alman, Arcan Yayınları, İstanbul, 2010.

Ali Vahid, Çanakkal'a Cephesi'nde Duyup Düşündüklerim, Darü'l-Hilafeti'l-illmiyye-Necm-i İstikbal Matbaası, İstanbul 1332-1334.

İğdemir, U. (Yay. Haz.), Arıburnu Muharebeleri Raporu, Türk Tarih Kurumu Yayınları, Ankara, 1990. İğdemir, U., Atatürk'ün Yaşamı (1881-1918), I, TTK Yayınları, Ankara, 1980.

James, R.R., Gelibolu Harekât, Çev: Haluk V. Saltkgil, Belge Yayınları, İstanbul, 1972.

Perk, K., Çanakkale Savaşının Tarihi 2 ve 3 ncü Kısımlar, Askeri Basımevi, İstanbul, 1940.

Roux, F.C., Çanakkale Seferi, Çev: Nihat ve Asım, Askeri Basımevi, İstanbul, 1921.

Yalçın, H.C., Siyasi Anılar, Türkiye İş Bankası Yayınları, İstanbul, 1976.

Yüzbaşı Celalettin, Kumkale Muharebeleri, Erkan-ı Harbiye Mektebi Yayınları, İstanbul, 1921.

Karahan, A., "Bir Arap İlmi Kurulu Gözü Ille Atatürk”, Hürriyet Gazetesi, 10-11 Kasım, İstanbul,1981.

Mercan, M., "Tarih Kaynağı Olarak Harp Cerideleri”, Tarih Dergisi, İstanbul, 2009, S.46, s.273-292.

Sebilü'r-Reşad, C.14 (29 Teşrin-i evvel 1331, İstanbul, 1331, s.102-103.

Ünaydın, R.E., “Mülakatlar VI: Mustafa Kemal Paşa: Birinci Safha”, Çanakkale 5/8 Mart 1331/1915, Yeni Mecmua, Nüsha-i Fevkalade, Hilal Matbaası, İstanbul, 1334/1918. 